\title{
Impacts of 2006 Indonesian fires and dynamics on tropical upper tropospheric carbon monoxide and ozone
}

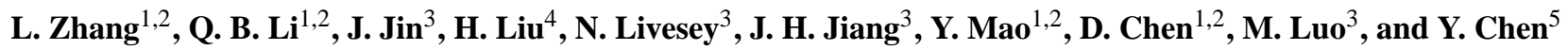 \\ ${ }^{1}$ Department of Atmospheric and Oceanic Sciences, University of California, Los Angeles, CA, USA \\ ${ }^{2}$ Joint Institute for Regional Earth System Science and Engineering, University of California, Los Angeles, CA, USA \\ ${ }^{3}$ Jet Propulsion Laboratory, California Institute of Technology, Pasadena, CA, USA \\ ${ }^{4}$ National Institute of Aerospace, Hampton, VA, USA \\ ${ }^{5}$ Department of Earth System Science, University of California, Irvine, CA 92697, USA
}

Received: 17 June 2011 - Published in Atmos. Chem. Phys. Discuss.: 6 July 2011

Revised: 26 October 2011 - Accepted: 26 October 2011 - Published: 4 November 2011

\begin{abstract}
We investigate the relative impacts of biomass burning emissions and dynamics on tropical upper tropospheric carbon monoxide $(\mathrm{CO})$ and ozone $\left(\mathrm{O}_{3}\right)$ over western and central Indonesia during the August-November 2006 fires in equatorial Asia by using a global three-dimensional model of tropospheric chemistry (GEOS-Chem) and by comparing model results with Microwave Limb Sounder (MLS) observations of upper tropospheric $\mathrm{CO}$ and $\mathrm{O}_{3}$. GEOS-Chem $\mathrm{CO}$ and $\mathrm{O}_{3}$ show similarities with MLS observed enhancements from convective lifting of fire emissions. In the tropical upper troposphere (UT), fire effluents from equatorial Asia are primarily transported southwestward to the eastern tropical Indian Ocean, driven by the high-pressure systems along $10^{\circ} \mathrm{N}-15^{\circ} \mathrm{N}$ and $10^{\circ} \mathrm{S}-15^{\circ} \mathrm{S}$ latitudes, and northeastward to southeast Asia and beyond, driven by the western North Pacific subtropical high. A characteristic feature of these $\mathrm{CO}$ enhancements is that they lag behind biomass burning emissions (by 2-3 weeks) at the three pressure levels 215,147 and $100 \mathrm{hPa}$, resulting from the decreasing influence of deep convective lifting with altitude in the tropical UT. Inclusion of biomass burning injection height significantly improves model comparison with observations. We estimate the fire influences by contrasting one model simulation with year-specific and another with climatological biomass burning emissions. Biomass burning accounts for about 50-150 ppbv of $\mathrm{CO}$ and 5-15 ppbv of $\mathrm{O}_{3}$ in the tropical UT below $100 \mathrm{hPa}$ during October and November, with temporal variations driven by biomass burning and deep convection. We estimate the dynamic impacts by examining the
\end{abstract}

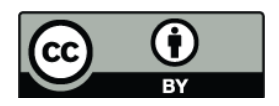

Correspondence to: Q. B. Li

(qli@atmos.ucla.edu) difference between a model simulation for 2006 (El Niño) and another for 2005 (neutral). The dynamic impacts are far more complex and account for up to $100 \mathrm{ppbv}$ of $\mathrm{CO}$ and $30 \mathrm{ppbv}$ of $\mathrm{O}_{3}$ in the tropical UT below $100 \mathrm{hPa}$. The temporal variation of the dynamic impact on $\mathrm{CO}$ is driven by deep convection. The variation of the dynamic impact on $\mathrm{O}_{3}$ depends on deep convection as well as the associated lightning $\mathrm{NO}_{\mathrm{x}}$ emissions and also reflects non-linearity of $\mathrm{O}_{3}$ chemistry.

\section{Introduction}

Smoke and excess tropospheric ozone $\left(\mathrm{O}_{3}\right)$ from biomass burning have long been observed over the tropics (Thompson et al., 2001). In equatorial Asia, large fires typically follow droughts during El Niño events (van der Werf et al., 2008a). Previous modeling studies have shown that dynamic processes related to El Niño events and the shift in the largescale Walker circulation also contributed to the observed enhancements in the tropospheric column $\mathrm{O}_{3}$ (TCO) over the equatorial Western Pacific during Indonesian fire seasons (Sudo and Takahashi, 2001; Chandra et al., 2002, 2004; Doherty et al., 2006). The fire emissions and the perturbed dynamics together result in variations in tropospheric composition (Chandra et al., 2002; Ziemke and Chandra, 2003). Doherty et al. (2006) showed that the TCO over equatorial Asia and the west Pacific was modulated by the El Niño-Southern Oscillation (ENSO). On the other hand, aerosols produced by these fires had strong influence on tropical atmospheric dynamics (Ott et al., 2010). There was a possible positive

Published by Copernicus Publications on behalf of the European Geosciences Union. 
feedback in which the anthropogenic burning in Indonesia enhanced drought stress during El Niño (Tosca et al., 2010).

These large fires significantly alter tropospheric composition including aerosol loading and tropospheric carbon monoxide (CO) and $\mathrm{O}_{3}$ (Duncan et al., 2003a). Duncan et al. (2007) used the Global Modeling Initiative (GMI) chemical transport model (CTM) to estimate that the Indonesian wildfires of 1997 increased CO by more than $40 \%$ in the tropical tropopause layer and by more than $10 \%$ in the lower stratosphere for several months after the fires. Their results also demonstrated that the increased presence of $\mathrm{CO}$ from the Indonesian fires could reduce atmospheric $\mathrm{OH}$ levels thereby increasing the atmospheric lifetimes and troposphere-to-stratosphere transport of trace gases. Chandra et al. (2002) studied the effects of forest fires in Indonesia during the $1997 \mathrm{El}$ Niño and found that about half of the increase in TCO was due to biomass burning and the other half was due to perturbed dynamics. Logan et al. (2008) examined observations from the Tropospheric Emissions Spectrometer (TES) to study the influences of the 2004 and 2006 El Niño events on tropical tropospheric profiles of $\mathrm{CO}, \mathrm{O}_{3}$ and water vapor. Their results showed that middle tropospheric $(511 \mathrm{hPa}) \mathrm{CO}$ and $\mathrm{O}_{3}$ mixing ratios were on average 80 ppbv and 15-30 ppbv larger in October and November 2006 than in the corresponding months of 2005 over Indonesia. GEOS-Chem model showed a similar spatial pattern to the observations with enhanced upper tropospheric $\mathrm{CO}$ over Indonesia and the Indian Ocean increasing from September to November 2006 and the enhancements disappearing in December (Liu et al., 2010). Nasssar et al. (2009) showed that, in the region of highest $\mathrm{CO}(\sim 200 \mathrm{ppbv})$ during the 2006 Indonesian fires, the contribution of the fires to the $\mathrm{O}_{3}$ enhancements was $45 \%$ in October, $75 \%$ in early November, and $10 \%$ in December. The same study found that dynamic changes increased $\mathrm{O}_{3}$ over a larger region than fire emissions, the latter increased $\mathrm{O}_{3}$ mainly at $10^{\circ} \mathrm{N}-10^{\circ} \mathrm{S}$ during October and November 2006. Ziemke et al. (2009) used satellite observations and the GMI model to estimate that fire emissions led to increases of tropospheric $\mathrm{O}_{3}$ mixing ratios over equatorial Asia by 15-25\% during the 2006 Indonesian fires. Chandra et al. (2009) used the GMI model to separate the dynamic effect of the 2006 El Niño from changes in fire emissions. They found that emissions and dynamic changes contributed almost equally to the observed $\mathrm{O}_{3}$ increases over Indonesia in October and November, though the $\mathrm{O}_{3}$ increases because of fire emissions were centered over Indonesia while those due to dynamic changes were over the Indian and western Pacific Oceans. The global burden of $\mathrm{CO}$ increased by $8-12 \%$ from October through December 2006 as a result of the fires (Chandra et al., 2009).

The emissions from the 2006 equatorial Asia fires (mostly in southern Borneo and Sumatra of Indonesia) were larger than any other years during 1997-2007 except 1997 (van der Werf et al., 2006, 2008a). Various satellite observations have shown enhanced CO levels throughout the tro- posphere during these fires (Logan et al., 2008; Rinsland et al., 2008; Chandra et al., 2009; Nassar et al., 2009). Many previous studies of the Indonesian fires, including the 2006 fires, have focused largely on the lower and middle tropospheric $\mathrm{CO}, \mathrm{O}_{3}$ and aerosols and on TCO. The upper troposphere (UT) is a highly coupled region where dynamics, chemistry, microphysics and radiation are fundamentally interconnected. Understanding the perturbations to the distributions of trace gases and aerosols in the UT is thus important for understanding climate change. In this study, we analyze Microwave Limb Sounder (MLS) measurements of CO and $\mathrm{O}_{3}$ to investigate the impact of the 2006 Indonesian fires on the tropical upper tropospheric $\mathrm{CO}$ and $\mathrm{O}_{3}$ over equatorial Asia. Our approach is to apply a global three-dimensional (3-D) chemical transport model (CTM) to interpret the observations. We intend to delineate the relative importance of fire emissions and dynamics in influencing the tropical upper tropospheric $\mathrm{CO}$ and $\mathrm{O}_{3}$ over equatorial Asia. We give a brief description of the 2006 Indonesian fires (August-November 2006) in Sect. 2. Section 3 presents MLS observations of upper tropospheric $\mathrm{CO}, \mathrm{O}_{3}$ and cloud ice water content (IWC). Model simulations of tropical upper tropospheric $\mathrm{CO}$ and $\mathrm{O}_{3}$ during the fires are discussed in Sect. 4. Section 5 investigates the sensitivity to biomass burning injection height. The relative impacts of biomass burning, dynamics and lightning $\mathrm{NO}_{\mathrm{x}}$ emissions on the tropical upper tropospheric $\mathrm{CO}$ and $\mathrm{O}_{3}$ are examined in Sect. 6. A summary and conclusions are presented in Sect. 7.

\section{The 2006 Indonesian fires}

Climate strongly regulates fire emissions and deforestation in equatorial Asia (van der Werf et al., 2008a, b). Previous studies have shown that fire emissions in equatorial Asia show strong interannual variability and increase significantly during El Niño (Bowen et al., 2001; Heil and Goldammer, 2001; van der Werf et al., 2006; Field and Shen, 2008; Field et al., 2009). The extended dry season during El Niño enables more effective use of fires for land management purpose, which often leads to widespread fires (van der Werf et al., 2008b). The extreme burning events are not linearly related to precipitation but rather increase abruptly when precipitation drops below a well-defined threshold (Field and Shen, 2008). Fires in Indonesia were intentionally set to clear out cropland and for industrial expansion during the dry season of El Niño. Some of these fires got out of control and led to extensive burning, for instance, in 1997 (Duncan et al., 2003 and references therein) and 2006 (ver der Werf et al., 2008). During the 2006 moderate El Niño, large and widespread fires occurred in Indonesia, Malaysia, and northern Australia during the extended dry season (August through November) (van der Werf et al., 2008a, b). Figure 1a shows the total CO emissions from August to November 2006 with largest emissions in southern Borneo, Sumatra, and northern Australia. The 

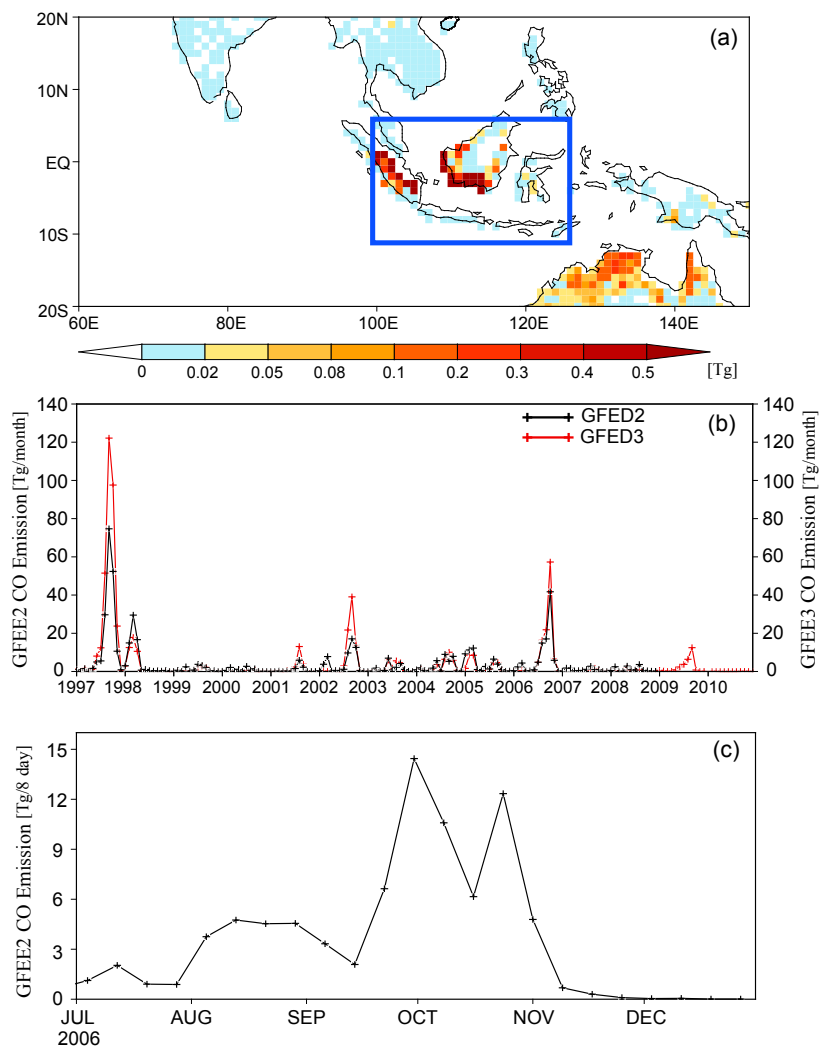

Fig. 1. Carbon monoxide emissions in 2006 over Indonesia and adjacent regions: (a) total emissions for August-November 2006 from GFED v2, (b) monthly emissions over Indonesia $\left(5^{\circ} \mathrm{N}-10^{\circ} \mathrm{S}\right.$, $100^{\circ} \mathrm{E}-125^{\circ} \mathrm{E}$ ) for $1997-2007$ from GFED v2 and GFED v3, and (c) emissions with 8-day temporal resolution over Indonesia from July to December 2006 from GFED v2.

emission data are from the Global Fire Emissions Database version 2 (GFED v2) (van der Werf et al., 2006). Much of our analysis focuses on western and central Indonesia (equator$10^{\circ} \mathrm{S}$ latitudes, $100^{\circ} \mathrm{E}-125^{\circ} \mathrm{E}$ longitudes), referred to hereafter as the WCI domain (the blue rectangle in Fig. 1a). The recently released GFED version 3 (v3) monthly data (van der Werf et al., 2010) is included here for comparison. Figure 1b shows GFED v2 (1997-2008) and v3 (1997-2010) monthly $\mathrm{CO}$ emissions for the WCI domain. Both databases show consistent interannual variability of biomass burning emissions. Large emissions occurred during the 1997, 2002, 2004, and 2006 El Niño in both databases, with v3 data showing larger emissions in these years. The 2009 emissions of CO are much smaller than those in 1997, 2002 and 2006, even though 2009 was also a moderate El Niño year. The emissions from Borneo during the 2006 fires were more than 30 times higher than the emissions during the 2000 La Niña (van der Werf et al., 2008). The 2006 fires started in August and lasted through late November (Fig. 1c). Peak emissions of CO are seen during both late September-early October and late October-early November. There is a secondary broad peak for much of August and early September. The $\mathrm{CO}$ emissions in October 2006 were several hundred times larger than the climatological values for this region.

\section{MLS observations of tropical upper tropospheric $\mathrm{CO}$ and $\mathrm{O}_{3}$}

The Microwave Limb Sounder (MLS) instrument (Waters et al., 2006) aboard the Aura spacecraft has been measuring atmospheric parameters since August 2004 (Schoeberl and Talabac, 2006). MLS uses microwave limb sounding to measure temperature and chemical constituents, including $\mathrm{CO}$, $\mathrm{O}_{3}$, water vapor, and cloud ice water content (IWC) in the UT and the stratosphere with a vertical resolution of $\sim 4.5 \mathrm{~km}$ and a horizontal resolution of $\sim 3^{\circ}$ along the orbit (Livesey et al., 2006). MLS chemical composition measurements in the UT are generally not degraded by the presence of clouds because the typical cloud particle sizes are much smaller than the wavelength of the radiation being observed. The $\mathrm{CO}, \mathrm{O}_{3}$ and cloud IWC observations used here are MLS retrieval version 3.3 (Livesey et al., 2011). The observations are averaged onto $2^{\circ}$ latitude $\times 5^{\circ}$ longitude grids for every five days. Our analysis focuses on the observations for pressure levels 215 , 147 , and $100 \mathrm{hPa}$. Biases of MLS upper tropospheric CO at $215 \mathrm{hPa}$ and partly at $146 \mathrm{hPa}$ in previous versions have been ameliorated in version 3.3 (Livesey et al., 2011).

MLS cloud IWC was derived from the $240 \mathrm{GHz}$ cloudinduced radiances at high tangent heights and is scientifically useful at 215-83 hPa (Wu et al., 2008). We include the IWC data in our analysis because it is a proxy for deep convection in the UT (Fu et al., 2006; Jiang et al., 2010, 2011): larger IWC indicates stronger deep convection. In addition to MLS cloud IWC data, we also examine NOAA outgoing longwave radiation (OLR) interpolated from satellite observations (Liebmann and Smith, 1996). OLR is a widely used proxy for deep convection with lower values indicating stronger deep convection (e.g., Randel et al., 2006; Logan et al., 2008; Nassar et al., 2009). The OLR data are global daily data with a horizontal resolution of $2.5^{\circ} \times 2.5^{\circ}$. We averaged the OLR data for every five days as we did for MLS data. The year 2005 was a neutral year from an El Niño perspective. As in Chandra et al. $(2007,2009)$ and Logan et al. (2008), we choose August-November of 2005 as baseline for estimating El Niño-related changes in the corresponding months of 2006. Here we compare the IWC and OLR data between 2006 and 2005 to get a better understanding of the different deep convection activities over equatorial Asia between these two years. Figure 2 shows the differences of IWC (at 215 and $147 \mathrm{hPa}$ ) and OLR between 2006 and 2005, calculated as 2006 values minus those of 2005, from July to December over the WCI domain. Both the IWC and OLR data show that deep convective activities were considerably weaker in 2006 than in 2005 during October-December. 


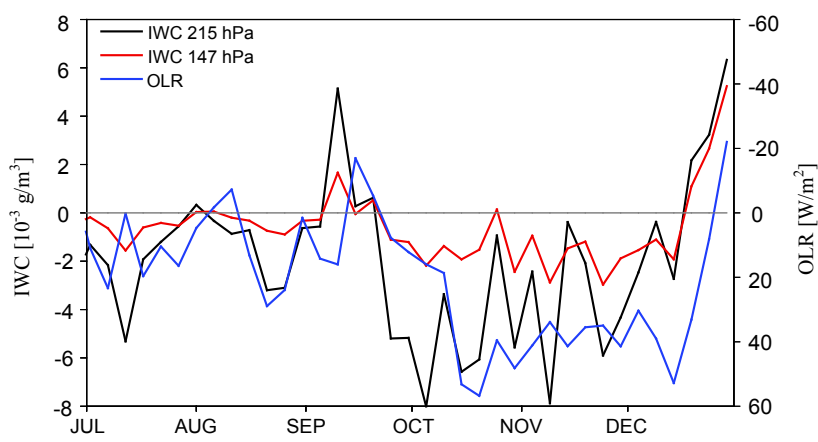

Fig. 2. MLS cloud ice water content (IWC) at $147 \mathrm{hPa}$ and $215 \mathrm{hPa}$ and NCEP/NCAR outgoing longwave radiation (OLR), calculated as the differences between 2006 and 2005. Values are averages over the Indonesia domain (see Fig. 1). Interpolated OLR data provided by the NOAA/OAR/ESRL PSD, Boulder, Colorado, USA, from their website at http://www.esrl.noaa.gov/psd/.

Figure 3 shows MLS CO (5-day averages) in the tropical UT at 215,147 and $100 \mathrm{hPa}$ for 2005 and 2006. Again, we included 2005 here for comparison because it was a neutral year with considerably smaller fire emissions than those in 2006 (Fig. 1b). Strongly enhanced CO concentrations are clearly evident from August to November 2006 at all three pressure levels, with maximum $\mathrm{CO}$ concentrations exceeding $150 \mathrm{ppbv}$ at 215 and $147 \mathrm{hPa}$ and $110 \mathrm{ppbv}$ at $100 \mathrm{hPa}$. At 215 and $147 \mathrm{hPa}$, the year-over-year enhancements during October-November are more than $70 \%$ from 2005 to 2006. The enhancements are widespread between $20^{\circ} \mathrm{S}$ and $10^{\circ} \mathrm{N}$ latitudes. Some noticeable time lags are seen in the $\mathrm{CO}$ enhancements among the pressure levels - the enhancements at $100 \mathrm{hPa}$ lag those at $147 \mathrm{hPa}$ and the latter lag behind those at $215 \mathrm{hPa}$. These time lags likely reflect the gradual upward propagation (via advection) of the convectively lofted surface biomass burning emissions (Liu et al., 2010). Correspondingly, the $\mathrm{CO}$ concentrations from the Tropospheric Emission Spectrometer (TES) (Beer et al., 2001) retrievals also showed a very strong maximum over Indonesia and the Indian Ocean, with peak concentrations exceeding $200 \mathrm{ppbv}$ in October and November in the lower troposphere (825$511 \mathrm{hPa}$ ) (Logan et al., 2008; Nassar et al., 2009). In addition, both very high $\mathrm{CO}$ concentrations in the middle to upper troposphere (400-200 hPa) observed by the Atmospheric Chemistry Fourier Transform Spectrometer (ACEFTS) (Rinsland et al., 2008) and high CO columns by the Measurement Of Pollution In The Troposphere (MOPITT) instrument (Yurganov et al., 2008) were also seen over the same broad region during the 2006 Indonesian fires. These observations clearly show that the biomass burning emissions from the large 2006 Indonesian fires significantly enhanced the $\mathrm{CO}$ concentrations in the middle to upper troposphere over the region. The biomass burning emissions from northern Australia (Fig. 1a) likely also contributed to these

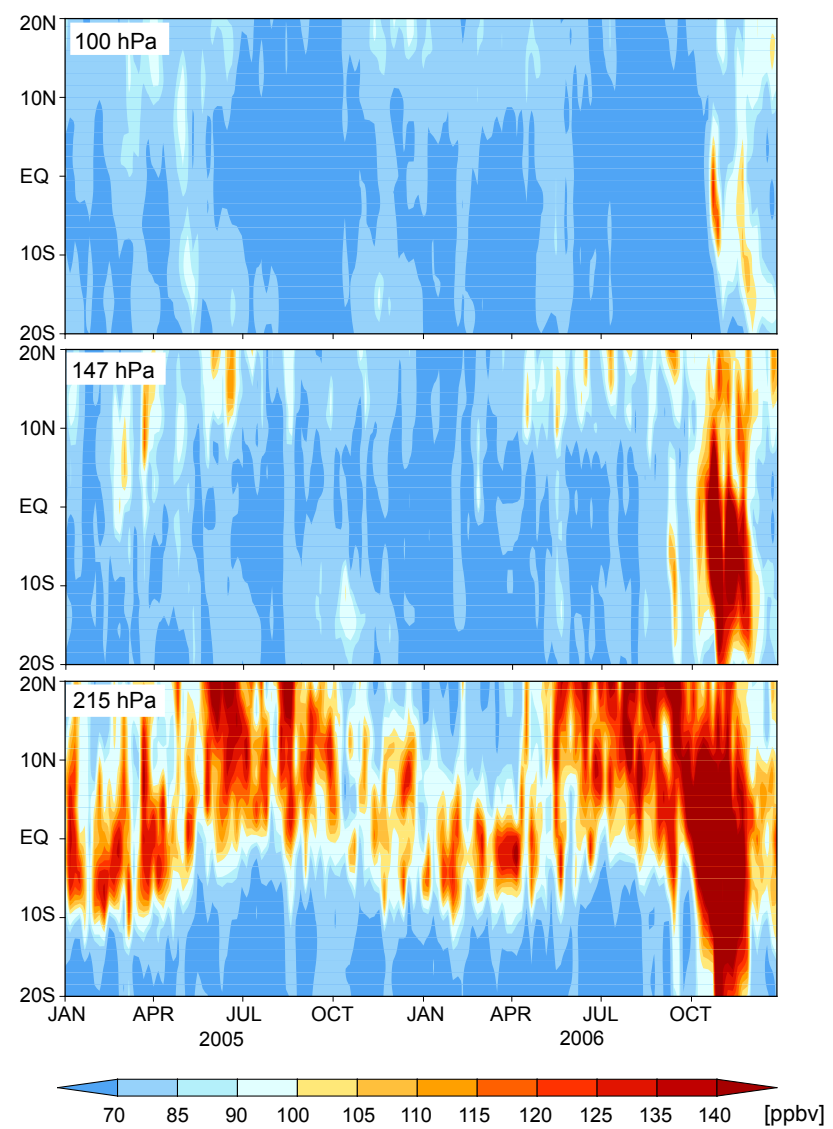

Fig. 3. Time-latitude cross-sections of MLS (v3.3) CO concentrations at $100 \mathrm{hPa}, 147 \mathrm{hPa}$, and $215 \mathrm{hPa}$ from January 2005 to December 2006 . Values are averages over $100 \mathrm{E}^{\circ}-125^{\circ} \mathrm{E}$ longitudes.

enhancements. We will address the Australia fire contribution in subsequent sections.

Figure 4 shows the time-latitude cross-sections of $\mathrm{MLS} \mathrm{O}_{3}$ (5-day averages) at 215, 147 and $100 \mathrm{hPa}$ for 2005 and 2006. Significant enhancements (relative to 2005) in $\mathrm{O}_{3}$ are clearly seen at $147 \mathrm{hPa}$ and to a lesser degree at $215 \mathrm{hPa}$ during October and November 2006. Ozone enhancements at $100 \mathrm{hPa}$ due to the Indonesian fires, if any, are difficult to quantify because of the already high background $\mathrm{O}_{3}$ concentrations near the tropical tropopause. The enhancements (relative to 2005 ) at $215 \mathrm{hPa}$ are mainly confined to south of the equator with increases of 15-20 ppbv during October and November 2006. It is probable that these enhancements were influenced by the emissions from the 2006 Indonesian fires. We will address that in the following sections.

\section{GEOS-Chem model description and simulations}

GEOS-Chem is a global 3-D CTM driven by assimilated meteorological observations from the Goddard Earth Observing System (GEOS) of the NASA Global Modeling and 


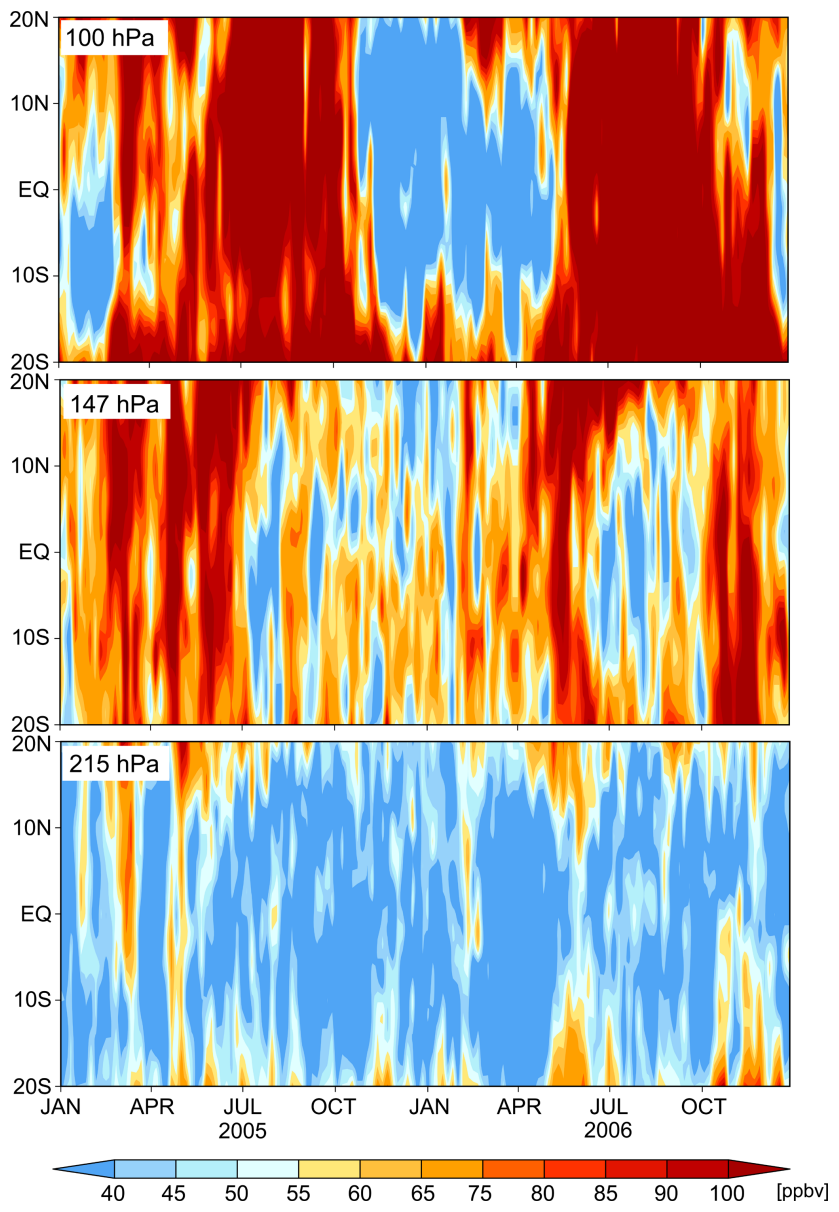

Fig. 4. Same as Fig. 2, but for $\mathrm{O}_{3}$.

Assimilation Office (GMAO) (Bey et al., 2001). We use GEOS-Chem version 8-01-04 (http://acmg.seas.harvard.edu/ geos/) driven by GEOS-4 and GEOS-5 meteorological fields with 6-h temporal resolution (3-h for surface variables and mixing depths), $2^{\circ}$ (latitude) $\times 2.5^{\circ}$ (longitude) horizontal resolution, and 30 (GEOS-4) or 47 (GEOS-5) vertical layers between the surface and $0.01 \mathrm{hPa}$. The GEOS-Chem model includes a detailed description of tropospheric $\mathrm{O}_{3}$ $\mathrm{NO}_{\mathrm{x}}$-hydrocarbon chemistry coupled with aerosol chemistry (Bey et al., 2001). Gas phase chemical reaction rates and photolysis cross sections are from Sander et al. (2000). Photolysis frequencies are computed using the Fast-J algorithm (Wild et al., 2000).

Tracer advection is computed every 15 min with a fluxform semi-Lagrangian method (Lin and Rood, 1996). Tracer moist convection is computed using the GEOS convective, entrainment, and detrainment mass fluxes as described by Allen et al. (1996a, b). The deep convection scheme of GEOS-4 is based on Zhang and McFarlane (1995), and the shallow convection treatment follows Hack (1994). GEOS5 convection is parameterized using the relaxed ArakawaSchubert scheme (Moorthi and Suarez, 1992). ${ }^{222} \mathrm{Rn}$ is com- monly used as a tracer for diagnosing convection in CTMs (Jacob and Prather, 1990; Considine et al., 2005). Figure 5 compares the annual zonal mean distributions of ${ }^{222} \mathrm{Rn}$ for 2006 simulated by GEOS-Chem driven by GEOS- 4 and by GEOS-5 meteorological data. The tropical upper tropospheric ${ }^{222} \mathrm{Rn}$ concentrations are much higher in the model results from the simulation driven by GEOS-4 meteorological data than those from the simulation driven by GEOS-5 data. These differences indicate that the deep convection in the tropics, especially in the northern tropics, is significantly deeper in GEOS-4 than in GEOS-5 (Liu et al., 2010). GEOSChem simulations of the tropical upper tropospheric $\mathrm{CO}$ and $\mathrm{O}_{3}$ will undoubtedly bear these differences, as discussed in subsequent sections.

The fossil fuel emissions are from the Emission Database for Global Atmospheric Research (EDGAR) inventory for $\mathrm{NO}_{\mathrm{x}}, \mathrm{CO}$, and $\mathrm{SO}_{2}$ (Olivier et al., 2001) and from the Global Emission Inventory Activity (GEIA) for other chemical compounds (Benkovitz et al., 1996) with additional updates as described by Hudman et al. (2007). Asian anthropogenic emissions are updated with the estimates from Zhang et al. (2009). Biofuel emissions are from Yevich and Logan (2003). The biogenic VOCs emissions are based on the Model of Emissions of Gases and Aerosols from Nature (MEGAN) inventory (Guenther et al., 2006).

Emissions of lightning $\mathrm{NO}_{\mathrm{x}}$ in GEOS-Chem is computed locally in deep convection events following the scheme of Price and Rind (1992) that relates flash rates to convective cloud top heights. The emissions are vertically distributed following the profile from Pickering et al. (1998) where $55-75 \%$ of the emissions are above $8 \mathrm{~km}$. Implementation of the lightning source in GEOS-Chem is as described by Wang et al. (1998) with updates reported by Hudman et al. (2007) and Sauvage et al. (2007). To improve the spatial distribution of lightning in the model, the spatial distribution of lightning is scaled to reproduce seasonal mean lightning flash rates to match the climatological $(11 \mathrm{yr})$ satellite observations of lightning flashes from the Optical Transient Detector and Lightning Imaging Sensor (OTD/LIS) High Resolution Monthly Climatology (HRMC) v2.2 product (Sauvage et al., 2007; Nassar et al., 2009). Since only the seasonal scale factor is applied, the inter-annual variability of the lightning $\mathrm{NO}_{\mathrm{x}}$ emissions as represented by the model is retained.

Biomass burning emissions are from GFED v2 that resolves the interannual variability of biomass burning emissions (van der Werf et al., 2006; Randerson et al., 2006). GFED v2 is derived using satellite observations including active fire counts and burned areas in conjunction with the Carnegie-Ames-Stanford-Approach (CASA) biogeochemical model. Carbon emissions are calculated as the product of burned area, fuel load and combustion completeness. Burned area is derived using the active fire and 500-meter burned area datasets from the Moderate Resolution Imaging Spectroradiometer (MODIS) as described by Giglio et al. (2006). The original GFED v2 inventory has a spatial resolution of 


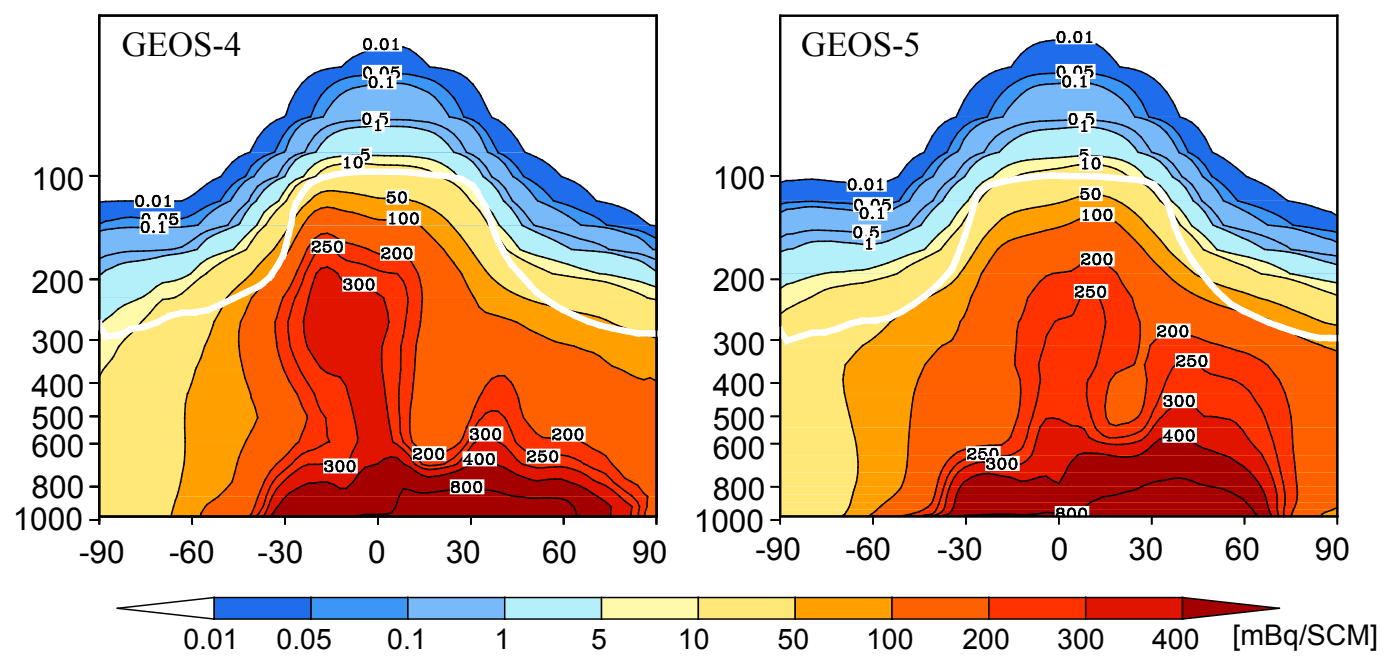

Fig. 5. Annual, zonal mean ${ }^{222} \mathrm{Rn}[\mathrm{mBq} / \mathrm{SCM}]$ from a GEOS-Chem simulation driven by GEOS-4 and GEOS-5 meteorological data for 2006. White line indicates the World Meteorological Organization (WMO) thermal tropopause.

$1^{\circ}$ (latitude) $\times 1^{\circ}$ (longitude) and a monthly temporal resolution. The emissions are re-sampled to $2^{\circ}$ (latitude) $\times 2.5^{\circ}$ (longitude) grids for use in our GEOS-Chem simulations. Forest fires typically last from several days to weeks as seen in MODIS active fires (Giglio et al., 2003). Therefore, we re-sampled GFED v2 monthly emissions to an 8-day time step according to MODIS 8-day active fire counts (Chen et al., 2009). The GFED v2 8-day emissions are used for the model simulations presented here unless stated otherwise. In GFED v3, a revised version of the CASA model, improved satellite-derived estimates of area burned, fire activity, and plant productivity were used to calculate fire emissions. We include GFED v3 emissions for comparison where appropriate. Additionally, climatological biomass burning emissions with seasonal variation from Duncan et al. (2003a) are used in two of the model simulations for comparison. The average seasonal variation is constrained from four years (1996 to 2000, including the 1997 El Niño) of fire count data from the Along Track Scanning Radiometer (ATSR) and two years (1992-1994) of similar data from the Advanced Very High Resolution Radiometer (AVHRR) World Fire Atlases (Duncan et al., 2003a).

We conducted model simulations for 2006 and 2005 driven by either GEOS-4 or GEOS-5 meteorological data. Either the GFED v2 8-day or the Duncan et al. (2003a) climatological inventory was used in these simulations. Justifications for these simulations are provided where appropriate. The details for these experiments are summarized in Table 1 . For direct comparison with MLS observations, we extracted model results at the time and location of the observations and applied the same 5-day averaging as we did for the observations (see Sect. 2).

Our standard simulation (experiment A) is driven by GEOS-4 meteorological data and with GFED v2 8-day emis-
Table 1. Description of model experiments.

\begin{tabular}{ccll}
\hline Experiment & Year & $\begin{array}{l}\text { Meteorological } \\
\text { data }\end{array}$ & $\begin{array}{l}\text { Biomass burning } \\
\text { emissions }\end{array}$ \\
\hline A & 2006 & GEOS-4 & GFED v2 8-day for 2006 \\
A1 & 2006 & GEOS-4 & Monthly climatology \\
A2 & 2005 & GEOS-4 & GFED v2 8-day for 2006 \\
B & 2006 & GEOS-5 & GFED v2 8-day for 2006 \\
B1 & 2006 & GEOS-5 & Monthly climatology \\
B2 & 2005 & GEOS-5 & GFED v2 8-day for 2006 \\
\hline
\end{tabular}

sions for 2006. Figure 6 compares model simulated and MLS retrieved CO concentrations at 100, 147 and $215 \mathrm{hPa}$ for 2006 over equatorial Asia and northern Australia between $20^{\circ} \mathrm{S}$ and $20^{\circ} \mathrm{N}$ latitudes. The values shown are averages between $100^{\circ} \mathrm{E}$ and $125^{\circ} \mathrm{E}$ longitudes. GEOS-Chem CO shows similar seasonal cycles seen in MLS data at both 215 and $147 \mathrm{hPa}$ over the WCI domain $\left(20^{\circ} \mathrm{S}-5^{\circ} \mathrm{N}\right)$ : broad enhancements in spring, relatively low concentrations in summer, and large extensive enhancements during OctoberNovember. The correlation coefficient between model results and observations of $\mathrm{CO}$ averaged over the WCI domain are 0.82 for $215 \mathrm{hPa}, 0.81$ for $147 \mathrm{hPa}$, and 0.76 for $100 \mathrm{hPa}$ (significant at the $99 \%$ confidence level). In addition, model $\mathrm{CO}$ also captures the time lags in the October-November enhancements among the three pressure levels: the enhancements extend to well in December at 147 and $100 \mathrm{hPa}$. Model CO concentrations are generally lower than MLS data at all three pressure levels, with largest differences of more than $50 \mathrm{ppbv}$ at $100 \mathrm{hPa}$ during the peak fire season. Part of these discrepancies is due to the weak convection in the model hence insufficient convective lofting of surface biomass burning emissions to the tropical UT over equatorial Asia. Nassar 

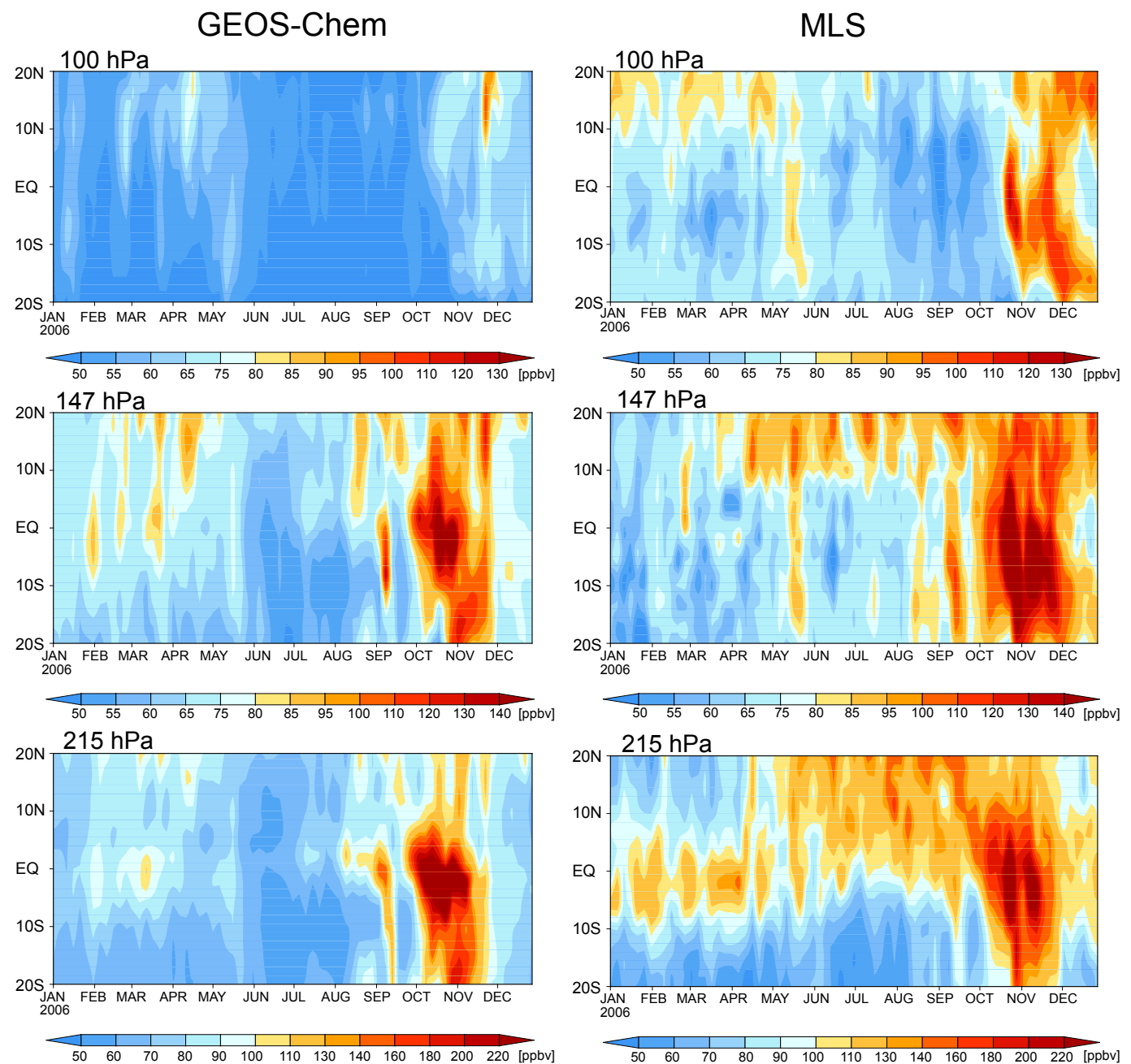

Fig. 6. Time-latitude cross-sections of GEOS-Chem simulated and MLS retrieved CO concentrations at $100 \mathrm{hPa}$ (top panels), $147 \mathrm{hPa}$ (middle panels) and $215 \mathrm{hPa}$ (bottom panels) for 2006 . Values are averages over the $100^{\circ} \mathrm{E}-125^{\circ} \mathrm{E}$ longitudes.

et al. (2009) compared GEOS-4 OLR with NOAA interpolated OLR for October and November 2006 and concluded that GEOS-4 convection was too weak over equatorial Asia. Additionally, part of the discrepancies is explained by the positive biases in MLS CO at these pressure levels despite significant bias reductions in MLS v3.3 data (Livesey et al., 2006, 2011). Previous studies have shown that outflow of anthropogenic CO from East Asia were transported in the UT to tropical South and Southeast Asia (Liu et al., 2003; Li et al., 2005). The lower concentrations simulated by the model at the northern edge of the domain thus likely reflect in part the insufficient transport of anthropogenic CO from East (and Southeast) Asia in the model.

Figure 7 shows GEOS-Chem simulated and MLS observed spatial distributions of monthly averaged $\mathrm{CO}$ concentrations at $215 \mathrm{hPa}$ in October and November 2006. Also shown are streamlines from the NCEP/NCAR reanalysis data. Significant enhancements of $\mathrm{CO}$ concentrations are seen over equatorial Asia in both the model results and the observations. The spatial extents of the enhancements are larger in the observations than in the model results, especially in November. Sandwiched by the high-pressure systems along $10^{\circ} \mathrm{N}-15^{\circ} \mathrm{N}$ and $10^{\circ} \mathrm{S}-15^{\circ} \mathrm{S}$ latitudes, the outflow of biomass burning $\mathrm{CO}$ in both months is mainly to the Eastern tropical Indian Ocean in both hemispheres. Northeastward outflow to Southeast Asia under the influence of the western North Pacific subtropical high, both in the observations and in the model, is also evident. We find similar $\mathrm{CO}$ outflow patterns at $147 \mathrm{hPa}$ (not shown).

Figure 8 shows GEOS-Chem simulated and MLS observed $\mathrm{O}_{3}$ at 215 and $147 \mathrm{hPa}$ for 2006. Values are averages over the $100^{\circ} \mathrm{E}-125^{\circ} \mathrm{E}$ longitudes. At $215 \mathrm{hPa}$, the highest $\mathrm{O}_{3}$ levels during October-December are seen over the southern tropics extending from the equator to $20^{\circ} \mathrm{S}$ in both the observations and the model results. The observed high $\mathrm{O}_{3}$ concentrations in May are less obvious in the model results. 

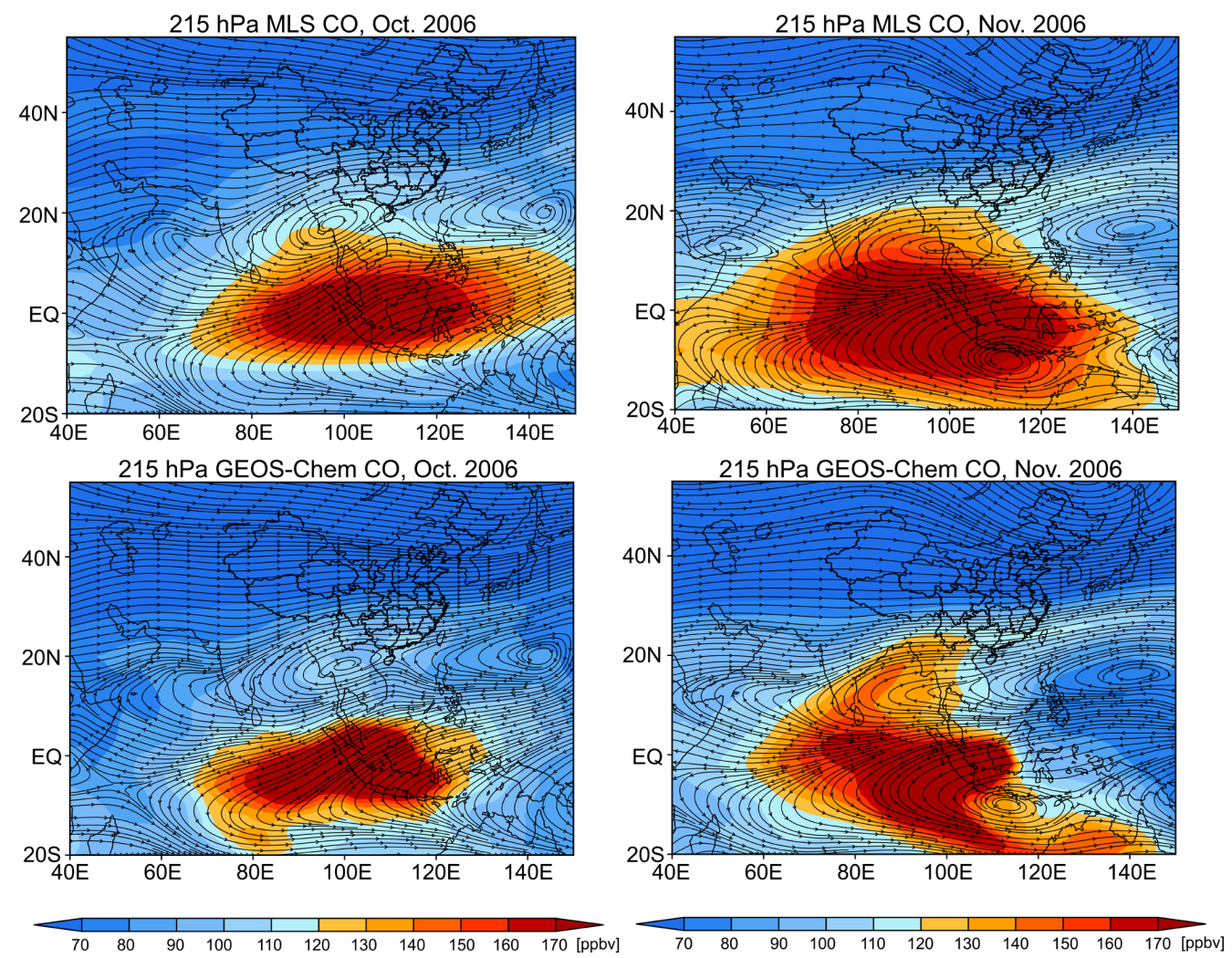

Fig. 7. MLS observed (top panels) and GEOS-Chem simulated (bottom panels) CO concentrations at $215 \mathrm{hPa}$ in October (left panels) and November (right panels) 2006. Also shown are streamlines from NCEP reanalysis data.

\section{GEOS-Chem}
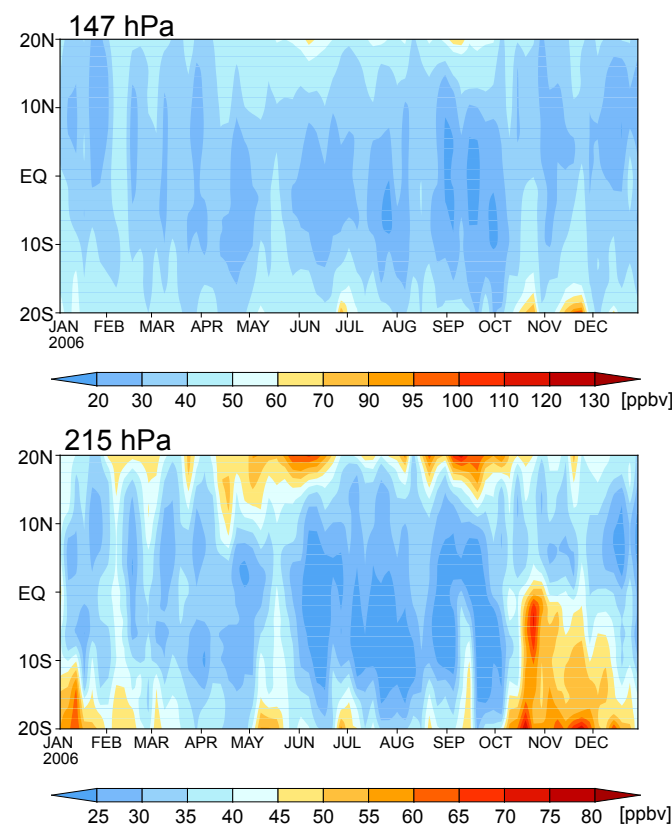

MLS
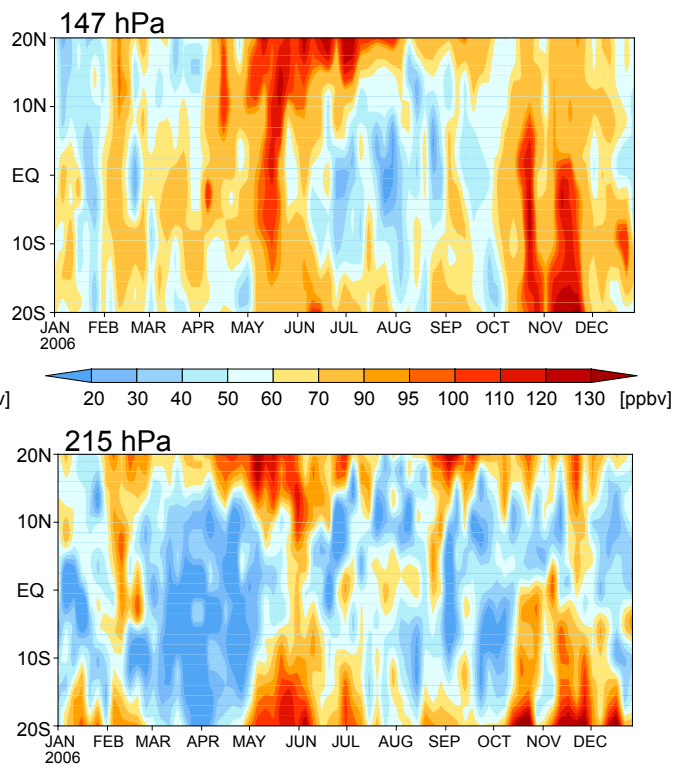

$\begin{array}{lllllllllllllllllll} & \mid & & \mid & \mid & \mid & \mid & \mid & \mid & \mid & & & \\ 25 & 30 & 35 & 40 & 45 & 50 & 55 & 60 & 65 & 70 & 75 & 80 & \text { [ppbv] }\end{array}$

Fig. 8. Same as Fig. 6, but for $\mathrm{O}_{3}$. 

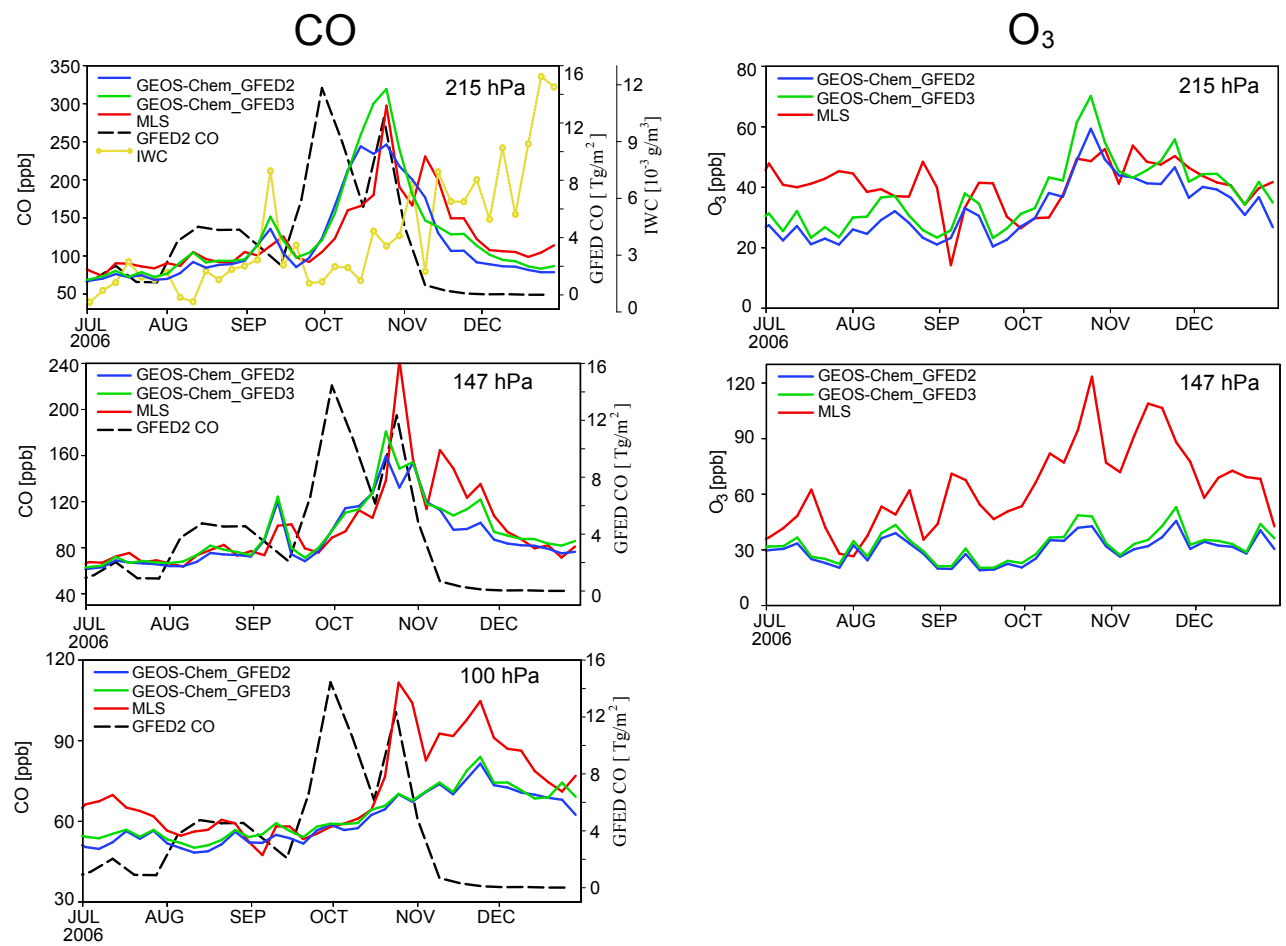

Fig. 9. Upper tropospheric $\mathrm{CO}$ and $\mathrm{O}_{3}$ concentrations over the WCI (see Fig. 1) from July to December 2006 of MLS and GEOS-Chem CO and $\mathrm{O}_{3}$ driven by GFED v2 and GFED v3 at 215, 147 and $100 \mathrm{hPa}$. Also shown in the top left panel are GFED v2 8-day CO emissions and $215 \mathrm{hPa}$ MLS ice water content (IWC).

These high $\mathrm{O}_{3}$ concentrations in May appear to be a recurring feature and are related to lightning $\mathrm{NO}_{\mathrm{x}}$ emissions (Zhang et al., 2011). The observations show high $\mathrm{O}_{3}$ concentrations at $147 \mathrm{hPa}$ during late October-November while the model results show correspondingly considerably lower values. The correlation coefficients between simulated and observed $\mathrm{O}_{3}$ averaged over the WCI domain are 0.51 for $215 \mathrm{hPa}$ (significant at the $99 \%$ confidence level) and 0.22 for $147 \mathrm{hPa}$ (significant at the $90 \%$ confidence level). The $100 \mathrm{hPa}$ pressure level is either at or close to the tropical tropopause where the already high $\mathrm{O}_{3}$ concentrations make it challenging to detect $\mathrm{O}_{3}$ enhancements, if any, due to convectively lifted biomass burning emissions.

It is conceivable that biomass burning emissions in northern Australia during October and November 2006 (Fig. 1a) may contribute to the upper tropospheric $\mathrm{CO}$ over equatorial Asia. Luo et al. (2010) examined satellite observations of CO during 11-19 December 2006 from MLS and TES downwind of the Australian fires. They found significant amount of northern Australia biomass burning emissions lifted to the middle and upper troposphere. To quantify the influence of northern Australia fire emissions on tropical upper tropospheric $\mathrm{CO}$ and $\mathrm{O}_{3}$, we conducted a GEOS-Chem sensitivity simulation where biomass burning emissions in Australia $\left(110^{\circ} \mathrm{E}-179^{\circ} \mathrm{E}, 11^{\circ} \mathrm{S}-50^{\circ} \mathrm{S}\right)$ were shut off. The differences with the standard simulation (experiment A) thus represent the effect of Australia biomass burning emissions. The results (not shown) show that northern Australia biomass burning has rather small influences on the tropical upper tropospheric $\mathrm{CO}$ (less than $10 \mathrm{ppbv}$ or $6 \%$ of the total $\mathrm{CO}$ ) and $\mathrm{O}_{3}$ (less than $4 \mathrm{ppbv}$ or $4 \%$ of the total $\mathrm{O}_{3}$ ) over the WCI domain.

Figure 9 shows MLS observed and GEOS-Chem simulated $\mathrm{CO}$ at 215,147 and $100 \mathrm{hPa}$ and $\mathrm{O}_{3}$ at 215 and $147 \mathrm{hPa}$ over the WCI domain from July to December 2006. Model results from simulations with both GFED v2 and v3 emissions are included for comparison. Also shown are MLS cloud IWC at $215 \mathrm{hPa}$ as a proxy for deep convection. Differences between model results using GFED v2 and v 3 emissions are rather small except during the peak burning in late October. Therefore, results presented hereafter are from GEOS-Chem simulations with only GFED v2 emissions unless stated otherwise. The maximum MLS CO concentrations are seen during late October with more than $300 \mathrm{ppbv}$ at $215 \mathrm{hPa}, 240 \mathrm{ppbv}$ at $147 \mathrm{hPa}$, and $110 \mathrm{ppbv}$ at $100 \mathrm{hPa}$. The second peaks in the MLS observations are seen in early November at 215 and $147 \mathrm{hPa}$. MLS CO started to increase in early October at 215 and $147 \mathrm{hPa}$, about 2-3 weeks after the onset of the fire season. The cloud IWC increased at the same time as the enhancements of MLS CO. The increased convection might possibly contribute to the increase of $\mathrm{CO}$ concentrations after the large biomass burning. Both 

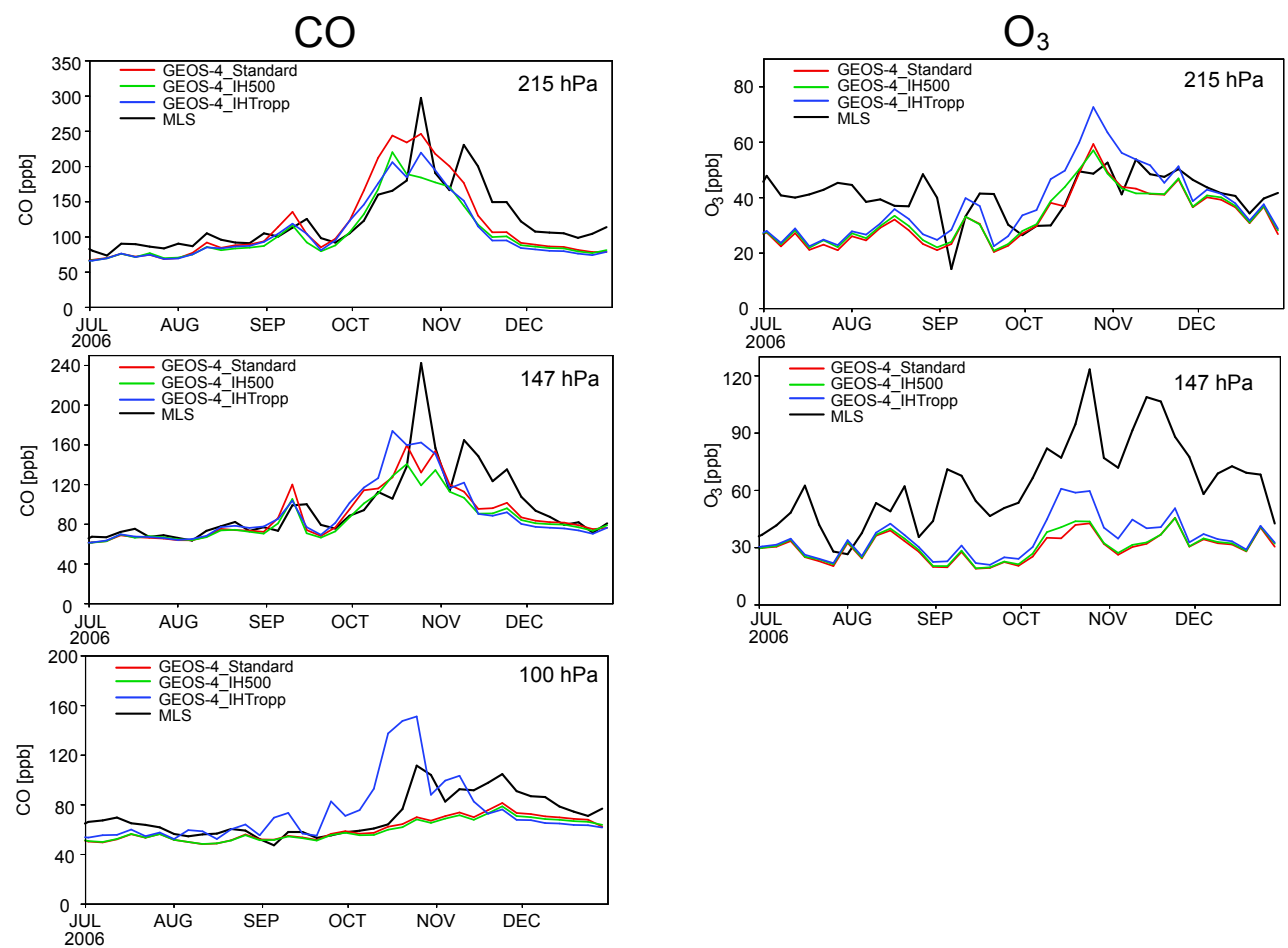

Fig. 10. MLS observed (black line) and GEOS-Chem simulated (driven by GEOS-4 meteorological data) upper tropospheric CO and $\mathrm{O}_{3}$ concentrations over the WCI (see Fig. 1) from July to December 2006. Model results from sensitivity simulations where biomass burning emissions are injected uniformly up to $500 \mathrm{hPa}$ (GEOS-4_IH500) and the tropopause (GEOS-4_IHTropp) as well as the standard simulation (GEOS-4 Standard) are shown. See text for detailed descriptions of the simulations.

MLS CO and GFED v2 emissions show two peaks with the same time lag. The largest $\mathrm{CO}$ enhancement is therefore a combined effect of both relatively stronger convection and large biomass burning emissions from the Indonesian fires. GEOS-Chem CO shows an extended maximum of CO concentrations at $215 \mathrm{hPa}$ from October to November. The enhancement is in broad agreement with the MLS observations, but the model underestimates the $\mathrm{CO}$ concentrations and the peaks in early November at 215 and $147 \mathrm{hPa}$ are absent in the model results. Nassar et al. (2009) showed that the GFED v2 emissions were likely too low in November 2006. Model CO at $147 \mathrm{hPa}$ shows elevated concentrations $(\sim 150 \mathrm{ppbv})$ during the second half of October. The peak concentrations at $147 \mathrm{hPa}$ are much lower in the model results than in the observations. In spite of the much larger emissions in GFED v3 than in GFED v2 during the peak burning in October (Fig. 1b), the CO concentrations at 147 and $100 \mathrm{hPa}$ are virtually the same, reflecting the decreasing vertical reach of deep convection above $215 \mathrm{hPa}$. The observed November enhancements at $147 \mathrm{hPa}$ are entirely absent in the model results. Part of the difference is again attributable to the weak deep convection in GEOS-4 during October and November 2006. Another factor is the insufficient vertical mixing above $200 \mathrm{hPa}$ in the model (Liu et al., 2010).
The MLS $\mathrm{O}_{3}$ concentrations also show similar double peaks at $147 \mathrm{hPa}$ and, to a lesser extent, $215 \mathrm{hPa}$ in October and November 2006, respectively (Fig. 9). GEOS-Chem $\mathrm{O}_{3}$, using GFED v2 and v3 data, shows variations consistent with MLS observations, with enhanced concentrations at $215 \mathrm{hPa}$ during September and October 2006. Model results are much lower than the observations at $147 \mathrm{hPa}$.

\section{Sensitivity to biomass burning injection height}

Biomass burning smoke plumes can be injected well above the planetary boundary layer (PBL) (Fromm et al., 2000, 2005; Fromm and Servranckx, 2003; Kahn et al., 2008). Modeling studies have shown that some smoke plumes need to be injected into the free troposphere for improved model comparison with observations (Turquety et al., 2007; Leung et al., 2007; Chen et al., 2009). We examine here the effect of plume injection height on the model simulation of tropical upper tropospheric $\mathrm{CO}$ and $\mathrm{O}_{3}$ over the WCI domain. In the standard GEOS-Chem simulation, biomass burning emissions are evenly distributed throughout the PBL, assuming fast boundary layer mixing (hereafter referred to as Standard). Obviously this approach underestimates emissions injected into the free troposphere. To examine the impact of plume injection height, we conducted GEOS-Chem 
simulations driven by GEOS-4 meteorological data with two additional treatments of biomass burning emissions in which biomass burning emissions were uniformly (in mass mixing ratio) distributed through the tropospheric column up to $500 \mathrm{hPa}$ (hereafter referred to as IH500) and up to the tropopause (hereafter referred to as IHTropp). The approach is similar to that used in several previous studies (Leung et al., 2007; Turquety et al., 2007; Hyer et al., 2007; Chen et al., 2009). It represents an extreme scenario in which certain percentages of emissions from each Indonesian fire were injected to the middle and upper troposphere. Again, we use GFED v2 emissions in these simulations. The results are shown in Fig. 10.

At $215 \mathrm{hPa}$, there is virtually little difference between CO concentrations from IH500 and IHtropp. Injecting biomass burning to above the PBL (hence reducing surface $\mathrm{CO}$ concentrations) in both cases effectively lowers $215 \mathrm{hPa}$ CO relative to the standard simulation. The results for $147 \mathrm{hPa}$ are rather similar among the three simulations, with $\mathrm{CO}$ concentrations from IHtropp somewhat higher and those from IH500 lower relative to the standard simulations. The fact that IH500 results in lower CO concentrations at $147 \mathrm{hPa}$ suggests that deep convection typically reaches above the middle troposphere over that region. At $100 \mathrm{hPa}$, injecting the emissions throughout the tropospheric column (IHtropp) leads to large, unrealistic enhancements of CO concentrations with peaks preceding those in MLS observations by about half a month. The overestimates and the temporal displacements both clearly point to the unrealistic nature of IHtropp. IH500 makes negligible changes relative to the standard simulation.

Injecting biomass burning emissions throughout the tropospheric column (IHtropp) significantly increases (relative to the standard simulation) the $\mathrm{O}_{3}$ concentrations at $215 \mathrm{hPa}$ during October 2006 and in fact worsens the model comparison with MLS observations. Injection of the emissions up to $500 \mathrm{hPa}$ (IH500) results in relatively little changes to $215 \mathrm{hPa} \mathrm{O}$. At $147 \mathrm{hPa}$, neither IHtropp, which leads to somewhat higher $\mathrm{O}_{3}$ (compared to the standard simulation) during October-November, nor IH500 significantly improves the model comparison with MLS observations.

\section{Effects of biomass burning, dynamics and lightning on upper tropospheric $\mathrm{CO}$ and $\mathrm{O}_{3}$}

The distribution of upper troposheric pollutants, such as $\mathrm{CO}$ and $\mathrm{O}_{3}$, can be influenced both by surface emission sources and by dynamic factors, such as convection and horizontal winds (e.g., Jiang et al., 2007). Chandra et al. (2007, 2009) have shown that both biomass burning and meteorological changes contributed almost equally to the observed increases in TCO over Indonesia during the dry seasons of the 1997 and the 2006 El Niño. We investigate here the relative influence of the 2006 Indonesian biomass burning and dynamics
Table 2. Contributions to tropical upper tropospheric $\mathrm{CO}$ and $\mathrm{O}_{3}$ concentrations over western and central Indonesia from biomass burning and dynamics. Values are averages for October and November 2006. Unit: ppbv.

\begin{tabular}{ccccccc}
\hline & & \multicolumn{2}{c}{ Biomass burning } & & \multicolumn{2}{c}{ Dynamics } \\
\cline { 3 - 4 } \cline { 6 - 7 } & & GEOS-4 & GEOS-5 & & GEOS-4 & GEOS-5 \\
\hline $\mathrm{CO}$ & $215 \mathrm{hPa}$ & 83 & 67 & & 21 & 10 \\
& $147 \mathrm{hPa}$ & 34 & 39 & & -1 & 18 \\
& $100 \mathrm{hPa}$ & 7 & 13 & & -6 & 3 \\
$\mathrm{O}_{3}$ & $215 \mathrm{hPa}$ & 6 & 5 & & 5 & 8 \\
& $147 \mathrm{hPa}$ & 2 & 4 & & 3 & 8 \\
\hline
\end{tabular}

on the tropical upper tropospheric $\mathrm{CO}$ and $\mathrm{O}_{3}$ over equatorial Asia. For this purpose we conducted two GEOS-Chem sensitivity simulations as summarized in Table 1 . We first conducted a model simulation driven by GEOS-4 meteorological data for 2006 (experiment A1) where the Duncan et al. (2003a) monthly mean climatological biomass burning emissions (with seasonal variation) were used in lieu of the GFED v2 8-day inventory for 2006 as used in experiment A, the standard simulation. Experiments A1 and A share the same configuration except for the aforementioned different biomass burning emission inventories used. The differences between the results from these two simulations, presented in Figs. 11a and 12a for the WCI domain, thus show the impact of enhanced biomass burning emissions. We then conducted a simulation driven by GEOS-4 meteorological data for 2005 (experiment A2) with otherwise the same configuration as the standard simulation. The differences between these two experiment results, shown in Figs. $11 \mathrm{~b}$ and $12 \mathrm{~b}$ for the WCI domain, therefore reflect the differences in the dynamics between the 2006 El Niño and 2005, a neutral year from an El Niño perspective. We discuss these differences as shown in Figs. 11 and 12 in more detail later in this section.

It is conceivable that the deep convection parameterizations used in the GEOS reanalysis system and the GEOSChem model strongly influence the abovementioned impacts. To examine this sensitivity, we conducted three GEOS-Chem simulations driven by GEOS-5 meteorological data (experiments B, B1, and B2), which differs significantly from GEOS-4 data in the deep convection scheme used (Sect. 4). Other than the GEOS-5 meteorological data used, experiments $\mathrm{B}, \mathrm{B} 1$, and $\mathrm{B} 2$ mirror experiments $\mathrm{A}, \mathrm{A} 1$, and $\mathrm{A} 2$, respectively. We can then examine the impacts of the 2006 Indonesian biomass burning emissions and dynamics with experiments B, B1, and B2 exactly as we do with experiments A, A1, and A2. The results are also shown in Figs. 11 and 12. The impact of the biomass burning and dynamics on upper tropospheric $\mathrm{CO}$ and $\mathrm{O}_{3}$ averaged in October and November is summarized in Table 2. 

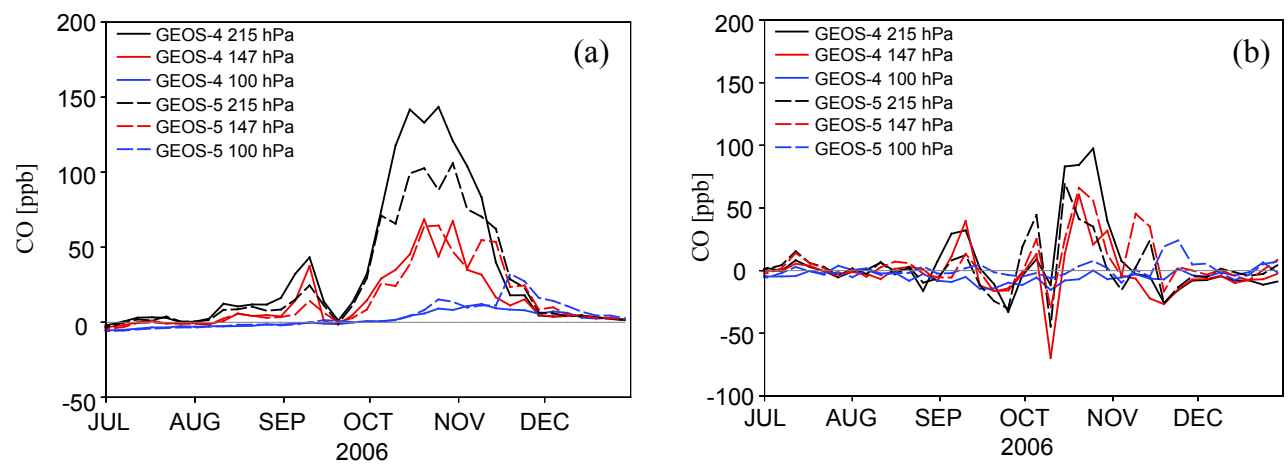

Fig. 11. Simulated upper tropospheric CO concentrations at 100, 147 and $215 \mathrm{hPa}$ determined as the differences between two GEOS-Chem simulations: (a) both for 2006, but one with GFED v2 biomass burning emissions for 2006 and the other with climatological biomass burning emissions and (b) one for 2006 and the other for 2005 and both with GFED v2 8-day biomass burning emissions for 2006. Results from GEOS-Chem simulations driven by GEOS-4 and GEOS-5 meteorological data are both shown. Values are averages over the Indonesia domain (see Fig. 1).
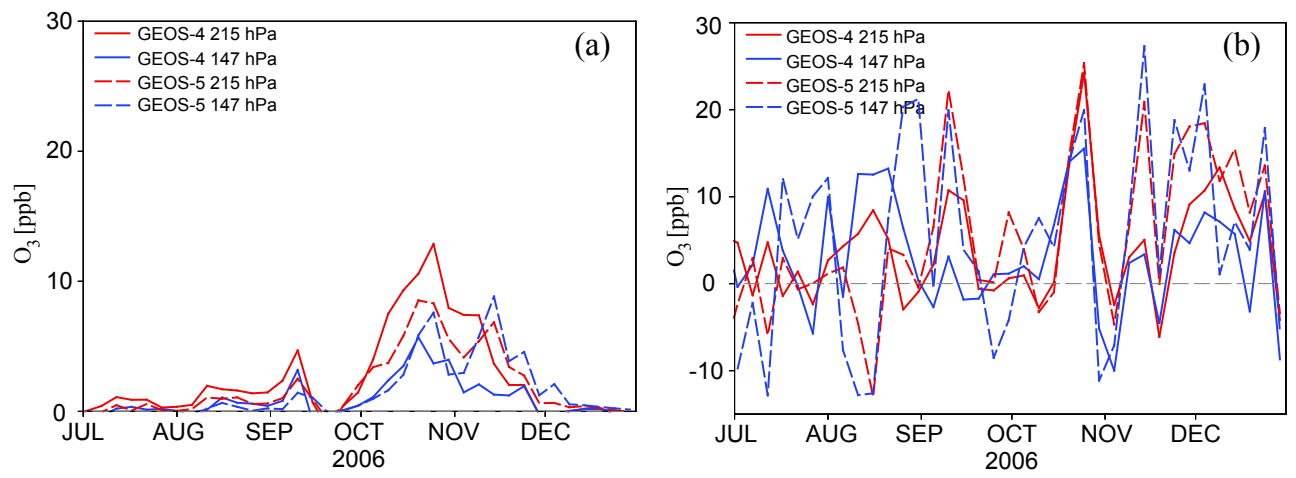

Fig. 12. Same as Fig. 10, but for $\mathrm{O}_{3}$ at 215 and $147 \mathrm{hPa}$.

\subsection{Biomass burning}

At $215 \mathrm{hPa}$, the largest biomass burning emissions contribute about 100 ppbv (GEOS-5) to 150 ppbv (GEOS-4), depending on the meteorological data used to drive the model simulations, to the $\mathrm{CO}$ enhancements during much of October and November 2006 (Fig. 11a). The model results thus show a persistent biomass burning impact on the upper tropospheric $\mathrm{CO}$ concentrations during the 2006 Indonesian fire season. At $215 \mathrm{hPa}$, the average $\mathrm{CO}$ enhancements in October-November, calculated as the difference between experiments A (B) and A1 (B1), referred to hereafter as AA1 (B-B1), are higher in A-A1 ( $~ 84$ ppbv, GEOS-4) than in B-B1 ( $\sim 67 \mathrm{ppbv}$, GEOS-5) by $\sim 17 \mathrm{ppbv}$. The stronger deep convection in GEOS-4 than in GEOS-5 (Fig. 5) largely explains the dependence of the model results on the meteorological data used. To reinforce this point, Fig. 13 compares the convective precipitation and cloud top height, both proxies for deep convection, from GEOS-4 and from GEOS5 during July-December 2006 averaged over the WCI domain. The convective precipitation is consistently larger and

the cloud top is higher in GOES-4 than in GEOS-5 through much of the period. In addition, Folkins et al. (2006) showed that deep convective detrainment in the upper troposphere is much stronger in GEOS-4 than in GEOS-3, with the latter having the same convection parameterization as GEOS5. The temporal variation of convective precipitation is also markedly different between GEOS-4 and GEOS-5 (Fig. 13a).

At $147 \mathrm{hPa}$, the biomass burning emissions contribute about 40-70 ppbv to the $\mathrm{CO}$ enhancements during middle to late October 2006 (Fig. 11a). The biomass burning influences for October 2006 are comparable between A-A1 (GEOS-4) and B-B1.(GEOS-5). The differences are largest in November when results from A-A1 decrease sharply through November while results from B-B1 show another maximum of 30-50 ppbv of $\mathrm{CO}$. The average contributions from biomass burning for October-November are $34 \mathrm{ppbv}$ from A-A1 and 39 ppbv from B-B1. Again, these differences are because of the different temporal variations of deep convection during October and November 2006 in GEOS-4 and GEOS-5 (Fig. 13). 

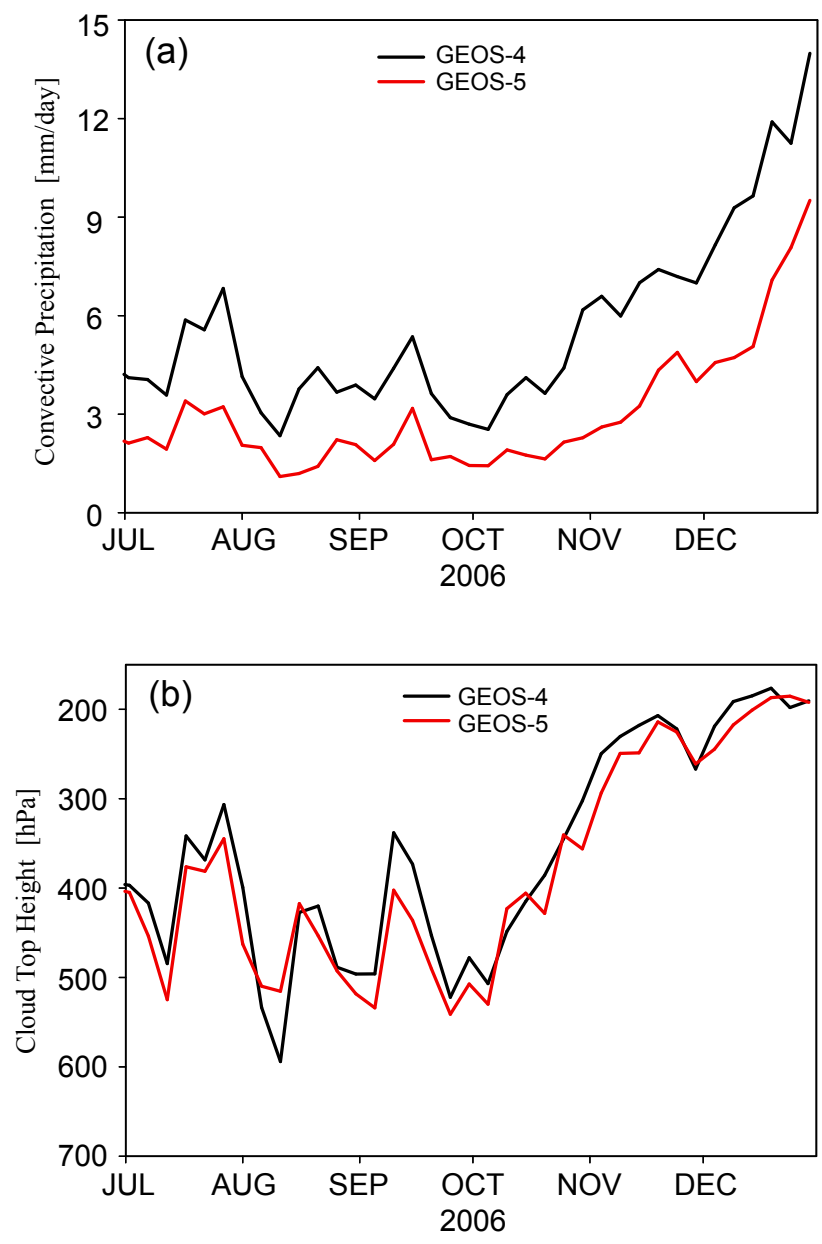

Fig. 13. GEOS-4 and GEOS-5 (a) deep convective precipitation rates and (b) cloud top height for July-December 2006 over the western and central Indonesian domain (see Fig. 1). Values are 5day averages.

Previous studies showed that during El Niño, both biomass burning and the changes in meteorological conditions including low convective activity, sparse precipitation, dry air condition, and large-scale dynamic changes contributed to the observed enhancements in TCO over equatorial Asia (Sudo and Takahashi, 2001; Chandra et al., 2002, 2009). Our model results show significantly enhanced $\mathrm{O}_{3}$ concentrations at both 215 and $147 \mathrm{hPa}$ because of the biomass burning emissions (Fig. 12a). For the same reason provided in previous sections, we do not include the model results at $100 \mathrm{hPa}$ in the discussion here. The biomass burning emissions contribute up to 5-15 ppbv in A-A1 (GEOS-4) and 5-10 ppbv in B-B1 (GEOS-5) to the $\mathrm{O}_{3}$ enhancements in the tropical UT during October and November 2006. At $215 \mathrm{hPa}$, the $\mathrm{O}_{3}$ enhancements during much of October and early November are consistently higher by up to 5 ppbv in model results from A-A1 than those from B-B1. At $147 \mathrm{hPa}$, the two sets of $\mathrm{O}_{3}$ enhancements are comparable during October but show large differences (up to $8 \mathrm{ppbv}$ ) during November. These differences again reflect the different strengths of deep convection in GEOS-4 and GEOS-5 data (Figs. 5, 13).

\subsection{Dynamics}

The influences from dynamics are more complex. The corresponding influences on $\mathrm{CO}$ at $215 \mathrm{hPa}$ from dynamics (Fig. 11b), calculated as the difference between experiments $\mathrm{A}(\mathrm{B})$ and $\mathrm{A} 2(\mathrm{~B} 2)$, referred to hereafter as A-A2 (BB2), amount up to about 30-60 ppbv in B-B2 (GEOS-5) to 80-100 ppbv in A-A2 (GEOS-4) of the CO enhancements during much of October 2006. In comparison, the biomass burning influences on $215 \mathrm{hPa} \mathrm{CO}$ are not only larger but also more extensive throughout October and November 2006 (Fig. 11a). Results from A-A2 show sharp decreases hence relatively small influence (less than $10 \mathrm{ppbv} \mathrm{CO}$ ) from dynamics during November 2006. In contrast, results from BB2 show decreases of up to $50 \mathrm{ppbv} \mathrm{CO}$ during late October and early November 2006 and CO enhancements of about 25 ppbv during middle November 2006. Clearly both the magnitudes and the temporal variations of the biomass burning and the dynamic impacts on $215 \mathrm{hPa} \mathrm{CO}$ differ between the model simulations driven by GEOS-4 versus GEOS-5 meteorological data. These differences are mostly because of the differing strengths and temporal variations of the deep convection in GEOS-4 and GEOS-5 (Figs. 5 and 13). The dynamic impacts at $147 \mathrm{hPa}$ (Fig. 11b) are comparable to the corresponding impacts at $147 \mathrm{hPa}$ from biomass burning emissions. The temporal variations of the biomass burning and the dynamic impacts at $147 \mathrm{hPa}$ track closely those at $215 \mathrm{hPa}$.

Deep convection rarely penetrates the tropical tropopause region (Alcala and Dessler, 2002; Gettelman et al., 2002). As such, both the biomass burning and the dynamic impacts on $\mathrm{CO}$ are relatively small (less than $10 \mathrm{ppbv}$ of $\mathrm{CO}$ ) at $100 \mathrm{hPa}$ (Fig. 11). The biomass burning impacts show notable time lags among the three pressure levels (Fig. 11a) while the dynamic impacts show no obvious time lags (Fig. 11b). The larger differences of biomass burning impacts on $\mathrm{CO}$ between 215 and $147 \mathrm{hPa}$ in GEOS-4 ( $\sim 100 \mathrm{ppbv} \mathrm{CO})$ than in GEOS-5 ( $\sim 50$ ppbv $\mathrm{CO})$ again reflects the different strengths of deep convection in the respective reanalysis data sets (Figs. 5, 13).

The dynamic impacts on $\mathrm{O}_{3}$ (from $\mathrm{A}-\mathrm{A} 2$ and $\mathrm{B}-\mathrm{B} 2$ ) are complex with $\mathrm{O}_{3}$ enhancements up to 20-30 ppbv at both 215 and $147 \mathrm{hPa}$ (Fig. 12b). The enhancements at 215 and $147 \mathrm{hPa}$ show similar temporal variations. The average enhancements during October-November are considerably higher in model results from B-B2 (GEOS-5) than those from A-A1 (GEOS-4), at both 215 and $147 \mathrm{hPa}$. The dynamic impacts on $\mathrm{O}_{3}$ show large and frequent fluctuation, which reflects the non-linearity of both the dynamics and the $\mathrm{O}_{3}$ chemistry. 

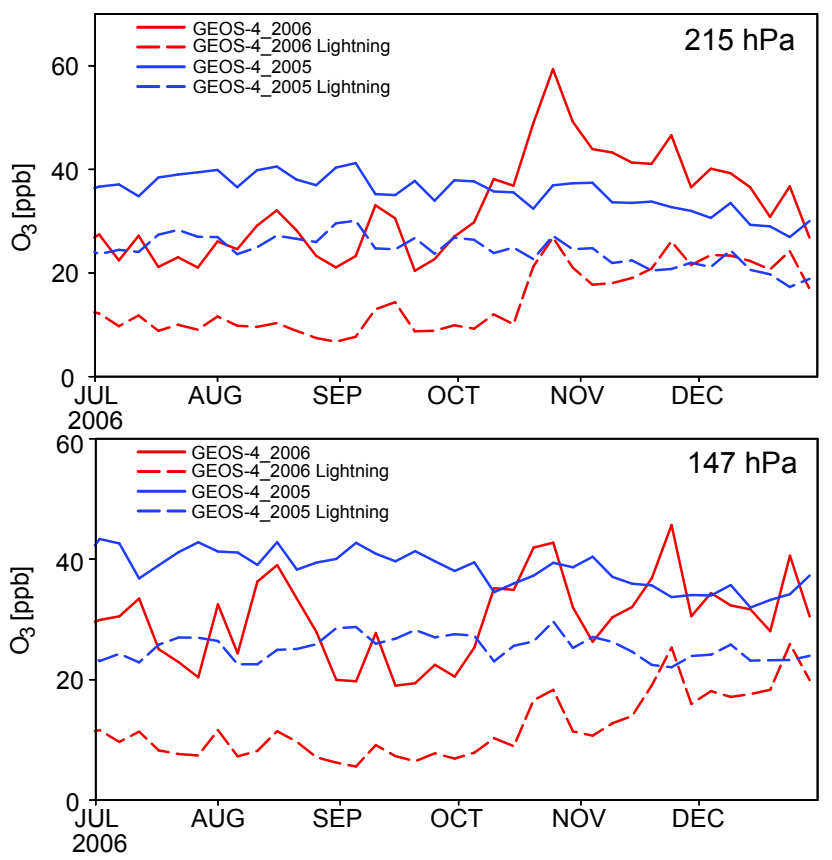

Fig. 14. Simulated upper tropospheric $\mathrm{O}_{3}$ concentrations with and without lightning $\mathrm{NO}_{\mathrm{x}}$ emissions from July to December of 2005 and 2006. Values are from GEOS-Chem simulations driven by GEOS-4 meteorological data and are averaged (5-day) over the WCI domain.

\subsection{Lightning}

Lightning $\mathrm{NO}_{\mathrm{x}}$ emissions strongly control tropical upper tropospheric $\mathrm{O}_{3}$ production (Sauvage et al., 2007; and references therein). Logan et al. (2008) suggested that lightning $\mathrm{NO}_{\mathrm{x}}$ was a major contributing factor to the positive anomaly in the TCO observed over equatorial Asia by TES during December 2006. Nassar et al. (2009) showed that lightning $\mathrm{NO}_{\mathrm{x}}$ emissions contributed about $5-15 \mathrm{ppbv}$ to the total $\mathrm{O}_{3}$ over the equatorial band around Indonesia during OctoberDecember 2006, with the largest contribution in the UT. Lightning $\mathrm{NO}_{\mathrm{x}}$ emissions in the GEOS-Chem model version used here are linked to deep convection (Sect. 4). Therefore, a portion of the dynamic impact on $\mathrm{O}_{3}$ shown in Fig. 12b is due to the different lightning activities between 2005 and 2006. But it is difficult to separate the lightning contribution from that of dynamics, given how the two are entangled in the model. Nevertheless, we conducted model simulations driven by GEOS-4 meteorological data with lightning $\mathrm{NO}_{\mathrm{x}}$ emissions turned off to quantify the lightning $\mathrm{NO}_{\mathrm{x}}$ contributions to the upper tropospheric $\mathrm{O}_{3}$. Figure 14 shows the simulated $\mathrm{O}_{3}$ concentrations and the associated lightning contributions in 2006 and in 2005 (overlaid on the same figure). Enhanced lightning contributions during October-December 2006 are clearly correlated with enhanced $\mathrm{O}_{3}$ at both 215 and $147 \mathrm{hPa}$. Overall the seasonal variation of lightning $\mathrm{NO}_{\mathrm{x}}$ contribution correlates very well with that of $\mathrm{O}_{3}$ concen-

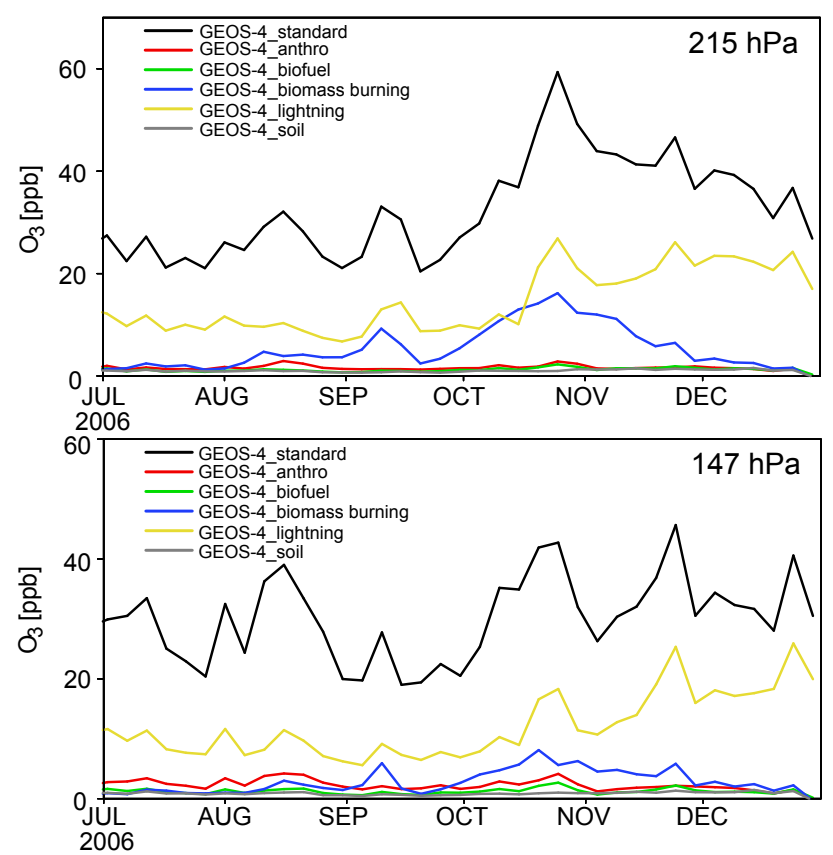

Fig. 15. GEOS-Chem simulated relative contributions to upper tropospheric $\mathrm{O}_{3}$ over the WCI domain from July to December 2006: biomass burning (blue line), lightning (yellow line), soil (grey line), biofuel (green line), and anthropogenic activities (red line). Also shown are total $\mathrm{O}_{3}$ from the standard simulation (black line). Values are 5-day averages.

tration for both 2005 and 2006. Lightning contributions in 2005 are comparable to those in 2006 with $\sim 15-20 \mathrm{ppbv}$ at $215 \mathrm{hPa}$ from middle October to December. At $147 \mathrm{hPa}$, however, the contributions are much larger in 2005 than in 2006. Again, it is worth pointing out that the lightning contribution calculated here is part of the dynamic impact discussed previously. To put the lightning contribution in perspective, we summarize in Fig. 15 the relative effects of $\mathrm{NO}_{\mathrm{x}}$ emissions from lightning, biomass burning, biofuel, anthropogenic sources and soil on upper tropospheric $\mathrm{O}_{3}$ during the 2006 Indonesian fires. The results are from model simulations driven by GEOS-4 meteorological data. Lightning represents the dominant contribution during July-December to the upper tropospheric $\mathrm{O}_{3}$ concentrations at both 215 and $147 \mathrm{hPa}$. At $215 \mathrm{hPa}$, biomass burning contribution is comparable to that of lightning during the September-November fire season. Lightning primarily and biomass burning to a lesser degree drive the $\mathrm{O}_{3}$ variability. The contributions from biofuel, anthropogenic and soil $\mathrm{NO}_{\mathrm{x}}$ emissions are comparatively small (less than 5 ppbv). 


\section{Summary and conclusions}

Observations from the Microwave Limb Sounder (MLS) showed significantly enhanced $\mathrm{CO}$ and $\mathrm{O}_{3}$ levels were observed in the tropical upper troposphere over equatorial Asia during the 2006 Indonesian fires from August to November. We investigated the effect of these fire emissions and dynamics on the tropical upper tropospheric $\mathrm{CO}$ and $\mathrm{O}_{3}$ by interpreting MLS observations using the GEOS-Chem model. The model captured the seasonal variations and special distributions of $\mathrm{CO}$ and $\mathrm{O}_{3}$ in the tropical upper troposphere over equatorial Asia. The biomass burning outflow as indicated by $\mathrm{CO}$ were primarily driven by tropical easterlies to the Indian Ocean and the western North Pacific subtropical high to the Southeast Asia. GEOS-Chem CO reproduced the distinct time lags between MLS observed CO enhancements at 215, 147 , and $100 \mathrm{hPa}$, reflecting in part the decreasing influence of deep convective lifting with altitude in the tropical upper troposphere. In addition, a time lag of about two weeks between the surface fire emissions and the $\mathrm{CO}$ enhancements in the upper troposphere was seen both in the MLS observations and in the model results. These $\mathrm{CO}$ enhancements corresponded with increased cloud ice water content.

Adjusting the injection heights from biomass burning emission above PBL plays an important role in improving the simulated upper tropospheric $\mathrm{CO}$ and $\mathrm{O}_{3}$. It elevated the upper tropospheric $\mathrm{CO}$ and $\mathrm{O}_{3}$ by distributing biomass burning emission uniformly up to the tropopause, but less significantly by adjusting the injection height to $500 \mathrm{hPa}$. However, it also produced unrealistic results due to factitiously fixing without involving the realistic vertical profiles.

The $\mathrm{CO}$ and $\mathrm{O}_{3}$ enhancements in the tropical upper troposphere over equatorial Asia reflected the combined effect of large surface biomass burning emissions from the 2006 Indonesian fires and the dynamic effect during the $2006 \mathrm{El}$ Niño. Biomass burning accounted for about 50-150 ppbv of $\mathrm{CO}$ and 5-15 ppbv of $\mathrm{O}_{3}$ in the tropical upper troposphere below $100 \mathrm{hPa}$ during October and November 2006, with temporal variations driven by biomass burning and deep convection. The dynamic impacts were complex and accounted for up to $100 \mathrm{ppbv}$ of $\mathrm{CO}$ and $30 \mathrm{ppbv}$ of $\mathrm{O}_{3}$ in the tropical upper troposphere below $100 \mathrm{hPa}$. The temporal variation of the dynamic impact on $\mathrm{CO}$ was driven by deep convection. The variation of the dynamic impact on $\mathrm{O}_{3}$ depended both on deep convection and the non-linearity of $\mathrm{O}_{3}$ chemistry. Lightning $\mathrm{NO}_{\mathrm{x}}$ emission contribution dominated the variation and production of upper tropospheric $\mathrm{O}_{3}$ and intimately intermingled with dynamics which is difficult to separate in the model since the lightning parameterization is based on cloud top height in the GEOS-4 convection. Biomass burning emission from the Indonesian fires was an major factor contributed to the upper tropospheric $\mathrm{O}_{3}$ enhancements other than the other than biofuel, anthropogenic activities and soil.
Acknowledgements. This research was supported in part by NASA grants NNX09AF07G and NNX08AF64G from the ACMAP program. We also acknowledge supports by the NASA Aura Science Team program. The GEOS-Chem model is managed by the Atmospheric Chemistry Modeling group at Harvard University with support from the NASA ACMAP program. Work at Jet Propulsion Laboratory, California Institute of Technology was done under contract with the National Aeronautics and Space Administration.

Edited by: B. N. Duncan

\section{References}

Alcala, C. M. and Dessler, A. E.: Observations of deep convection in the tropics using the Tropical Rainfall Measuring Mission (TRMM) precipitation radar, J. Geophys. Res., 107, 4792, doi:10.1029/2002JD002457, 2002.

Allen, D. J., Rood, R. B., Thompson, A. M., and Hidson, R. D.: Three-dimensional ${ }^{222} \mathrm{Rn}$ calculations using assimilated data and a convective mixing algorithm, J. Geophys. Res., 101, 68716881, 1996a.

Allen, D. J., Kasibhatla, P., Thompson, A. M., Rood, R. B., Doddridge, B. G., Pickering, K. E., Hudson, R. D., and Lin, S.-J.: Transport induced interannual variability of carbon monoxide using a chemistry and transport model, J. Geophys. Res., 101, 28655-28670, 1996b.

Benkovitz, C., Scholtz, M., Pacyna, J., Tarrasón, L., Dignon, J., Voldner, E., Spiro, P., Logan, J., and Graedel, T.: Global gridded inventories of anthropogenic emissions of sulfur and nitrogen, J. Geophys. Res., 101, 29239-29253, 1996.

Beer, R., Glavich, T. A., and Rider D. M.: Tropospheric Emission Spectrometer for the Earth Observing System AURA satellite, Appl. Opt., 40, 2356-2367, 2001.

Bey, I., Jacob, D. J., Yantosca, R. M., Logan, J. A., Field, B. D., Fiore, A. M., Li, Q. B., Liu, H. G. Y., Mickley, L. J., and Schultz, M. G.: Global modeling of tropospheric chemistry with assimilated meteorology: Model description and evaluation, J. Geophys. Res., 106, 23073-23096, 2001.

Chandra, S. and Ziemke, J. R.: Tropical tropospheric ozone: Implications for dynamics and biomass burning, J. Geophys. Res., 107, 4188, doi:10.1029/2001JD000447, 2002.

Chandra, S., Ziemke, J. R., Tie, X., and Brasseur, G., : Elevated ozone in the troposphere over the Atlantic and Pacific oceans in the Northern Hemisphere, Geophys. Res. Lett., 31, L23102, doi:10.1029/2004GL020821, 2004.

Chandra, S., Ziemke, J. R., Schoeberl, M. R., Froidevaux, L., Read, W. G., Levelt, P. F., and Bhartia, P. K.: Effects of the 2004 El Niño on tropospheric ozone and water vapor, Geophys. Res. Lett., 34, L06802, doi:10.1029/2006GL028779, 2007.

Chandra, S., Ziemke, J. R., Duncan, B. N., Diehl, T. L., Livesey, N. J., and Froidevaux, L.: Effects of the 2006 El Niño on tropospheric ozone and carbon monoxide: implications for dynamics and biomass burning, Atmos. Chem. Phys., 9, 42394249, doi:10.5194/acp-9-4239-2009, 2009.

Chen Y., Q. Li, Randerson, J. T., Lyons, E. A., Kahn, R. A., Nelson, D. L., and Diner, D. J.: The sensitivity of CO and aerosol transport to the temporal and vertical distribution of North Amer- 
ican boreal fire emissions, Atmos. Chem. Phys. 9, 6559-6580, doi:10.5194/acp-9-6559-2009, 2009.

Considine, D. B., Bergmann, D. J., and Liu, H.: Sensitivity of Global Modeling Initiative chemistry and transport model simulations of radon-222 and lead-210 to input meteorological data, Atmos. Chem. Phys., 5, 3389-3406, doi:10.5194/acp-5-33892005, 2005.

Doherty, R. M., Stevenson, D. S., Johnson, C. E., Collins, W. J., and Sanderson, M. G.: Tropospheric ozone and El Niño-Southern Oscillation: Influence of atmospheric dynamics, biomass burning emissions, and future climate change, J. Geophys. Res., 111, D19304, doi:10.1029/2005JD006849, 2006.

Duncan, B. N., Martin, R. V., Staudt, A., Yevich, R., and Logan, J. A.: Inter-annual and seasonal variability of biomass burning emissions constrained by satellite observations, J. Geophys. Res., 108, 4100, doi:10.1029/2002JD002378, 2003a.

Duncan, B. N., Bey, I., Chin, M., Mickley, L. J., Fairlie, T. D., Martin, R. V., and Matsueda, H.: Indonesian Wildfires of 1997: Impact on Tropospheric Chemistry, J. Geophys. Res., 108, 4458, doi:10.1029/2002JD003195, 2003b.

Duncan, B. N., Strahan, S. E., Yoshida, Y., Steenrod, S. D., and Livesey, N.: Model study of the cross-tropopause transport of biomass burning pollution, Atmos. Chem. Phys., 7, 3713-3736, doi:10.5194/acp-7-3713-2007, 2007.

Field, R. D. and Shen, S. S. P.: Predictability of carbon emissions from biomass burning in Indonesia from 1997 to 2006, J. Geophys. Res., 113, G04024, doi:10.1029/2008JG000694, 2008.

Field, R. D., van der Werf, G. R., and Shen, S. S. P.: Human amplification of drought-induced biomass burning in Indonesia since 1960, Nature Geosci., 2, 185-188, doi:10.1038/ngeo443, 2009.

Folkins, I., Bernath, P., Boone, C., Donner, L. J., Eldering, A., Lesins, G., Martin, R. V., Sinnhuber, B.-M., and Walker, K.: Testing convective parameterizations with tropical measurements of $\mathrm{HNO}_{3}, \mathrm{CO}, \mathrm{H}_{2} \mathrm{O}$, and $\mathrm{O}_{3}$ : Implications for the water vapor budget, J. Geophys. Res., 111, D23304, doi:10.1029/2006JD007325, 2006.

Fromm, M. and Servranckx R.: Transport of forest fire smoke above the tropopause by supercell convection, Geophys. Res. Lett., 30, 1542, doi:10.1029/2002GL016820, 2003.

Fromm, M., Alfred, J., Hoppel, K., Hornstein, J., Bevilacqua, R., Shettle, E., Servranckx, R., Li, Z., and Stocks, B.: Observations of boreal forest fire smoke in the stratosphere by POAM III, SAGE II, and lidar in 1998, Geophys. Res. Lett., 27, 14071410, 2000.

Fromm, M., Bevilacqua, R., Servranckx, R., Rosen, J., Thayer, J. P., Herman, J., and Larko, D.: Pyro-cumulonimbus injection of smoke to the stratosphere: Observations and impact of a super blowup in northwestern Canada on 3-4 August 1998, J. Geophys. Res., 110, D08205, doi:10.1029/2004JD005350, 2005.

Fu, R., Hu, Y., Wright, J. S., Jiang, J. H., Dickinson, R. E., Chen, M., Filipiak, M., Read, W. G., Waters, J. W., and Wu, D. L.: Short circuit of water vapor and polluted air to the global stratosphere by convective transport over the Tibetan Plateau, Proc. Natl. Acad. Sci., 103, 5664-5669, 2006.

Gettelman, A., Salby, M. L., and Sassi, F.: Distribution and influence of convection in the tropical tropopause region, J. Geophys. Res., 107, doi:10.1029/2001JD001048, 2002.

Guenther, A., Karl, T., Harley, P., Wiedinmyer, C., Palmer, P. I., and Geron, C.: Estimates of global terrestrial isoprene emissions using MEGAN (Model of Emissions of Gases and Aerosols from Nature), Atmos. Chem. Phys., 6, 3181-3210, doi:10.5194/acp-63181-2006, 2006.

Hack, J. J.: Parameterization of moist convection in the NCAR community climate model (CCM2), J. Geophys. Res., 99, 55515568, doi:10.1029/93JD03478, 1994.

Hudman, R. C., Jacob, D. J., Turquety, S., Leibensperger, E. M., Murray, L. T., Wu, S., Gilliland, A. B., Avery, M., Bertram, T. H., Brune, W., Cohen, R. C., Dibb, J. E., Flocke, F. M., Fried, A., Holloway, J., Neuman, J. A., Orville, R., Perring, A., Ren, X., Sachse, G. W., Singh, H. B., Swanson, A., and Wooldridge, P. J.: Surface and lightning sources of nitrogen oxides over the United States: Magnitudes, chemical evolution, and outflow, J. Geophys. Res., 112, D12S05, doi:10.1029/2006JD007912, 2007.

Hyer, E. J., Kasischke, E. S., and Allen, D. J.: Effects of source temporal resolution on transport simulations of boreal fire emissions, J. Geophys. Res., 112, D01302, doi:10.1029/2006JD007234, 2007.

Jacob, D. J. and Prather, M. J.: Radon-222 as a test of convection in a general circulation model, Tellus, 42, 118-134, 1990.

Jiang, J. H., Livesey, N. J., Su, H., Neary, L., McConnell, J. C., and Richards, N. A.: Connecting surface emissions, convective uplifting, and long-range transport of carbon monoxide in the upper-troposphere: New observations from the Aura MLS, Geophys. Res. Lett. 34, L18812, doi:10.1029/2007GL030638, 2007.

Jiang, J. H. Su, H., Pawson, S., Liu, H. C., Read, W., Waters, J. W., Santee, M., Wu, D. L., Schwartz, M., Livesey, N., Lambert, A., Fuller, R., and Lee, J. N.: Five-year (2004-2009) Observations of Upper Tropospheric Water Vapor and Cloud Ice from MLS and Comparisons with GEOS-5 analyses, J. Geophys. Res. 115, D15103, doi:10.1029/2009JD013256, 2010.

Jiang, J. H., Su, H., Zhai, C., Massie, S. T., Schoeberl, M. R., Colarco, P. R., Platnick, S., Gu, Y., and Liou, K. N.: Influence of convection and aerosol pollution on ice cloud particle effective radius, Atmos. Chem. Phys., 11, 457-463, doi:10.5194/ acp-11457-2011, 2011.

Leung, F.-Y. T., Logan, J. A., Park, R., Hyer, E., Kasischke, E., Streets, D., and Yurganov, L.: Impacts of enhanced biomass burning in the boreal forests in 1998 on tropospheric chemistry and the sensitivity of model results to the injection height of emissions, J. Geophys. Res., 112, D10313, doi:10.1029/2006JD008132, 2007.

Lin, S. J. and Rood, R. B.: Multidimensional flux form semiLagrangian transport schemes, Mon. Weather Rev., 124, 20462070, 1996.

Liu, H., Jacob, J. D., Bey, I., Yantosca. M. R., Duncan, B. N., and Sachse, G. W.: Transport pathways for Asian pollution outflow over the Pacific: Interannual and seasonal variations, J. Geophys. Res., 108, 8786, doi:10.1029/2002JD003102, 2003.

Liu J., Logan, J. A., Jones, D. B. A., Livesey, N. J., Megretskaia, I., Carouge, C., and Nedelec, P.: Analysis of CO in the tropical troposphere using Aura satellite data and the GEOS-Chem model: insights into transport characteristics of the GEOS meteorological products, Atmos. Chem. Phys., 10, 12207-12232, doi:10.5194/acp-10-12207-2010, 2010.

Livesey, N. J., Snyder, W. V., Read, W. G., and Wagner, P. A.: Retrieval algorithms for the EOS Microwave Limb Sounder (MLS) instrument, IEEE Trans. Geosci. Remote Sens., 44, 1144-1155, 2006. 
Livesey N. J., Read, G. W., Froidevaux, L., Lambert, A., Manney, L. G., Pumphrey, C. H., Santee, L. M., Schwartz, J. M., Wang, S., Cofield, E. R., Cuddy, T. D., Fuller A. R., Jarnot, F. R., Jiang, H. J., Knosp, W. B., Stek C. P., Wagner, A. P., and Wu L. D.: Version 3.3 Level 2 data quality and description document, JPL, 2011.

Lobert, J. M., Keene, W. C., Logan, J. A., and Yevich, R. : Global chlorine emissions from biomass burning: Reactive chlorine emissions inventory, J. Geophys. Res., 104, 8373-8389, 1999.

Logan, J. A., Megretskaia, I., Nassar, R., Murray, T. L., Zhang, L., Bowman, W. K., Worden, W. H., and Luo M.: Effects of the 2006 Elo Niño on tropospheric composition as revealed by data from the Tropospheric Emission Spectrometer (TES), Geophys. Res. Lett., 35, L03816, doi:10.1020/2007GL031698, 2008.

Luo, M., Boxe, C., Jiang, J., Nassar, R., and Livesey, N.: Interpretation of Aura satellite observations of $\mathrm{CO}$ and aerosol index related to the December 2006 Australia fires, Remote Sens. Environ., 114, 2853-2862, 2010.

Moorthi, S. and Suarez, M. J.: Relaxed Arakawa-Schubert: A parameterization of moist convection for general circulation models, Mon. Weather Rev., 120, 978-1002, 1992.

Nassar, R., Logan, J. A., Megretskaia, I. A., Murray, L. T., Zhang, L., and Jones, D. B. A.: Analysis of tropospheric ozone, carbon monoxide and water vapor during the 2006 El Niño using TES observations and the GEOS-Chem model, J. Geophys. Res., 114, D17304, doi:10.1029/2009JD011760, 2009.

Olivier, J. G. J. and Berdowski J. J. M.: Global emissions sourcesand sinks, in The Climate System, edited by: Berdowski, J., Guicherit, R., and Heij, B. J., Balkema, A. A., Lisse, The Netherlands, 33-78, 2001.

Ott, L., Duncan, B., Pawson, S., Colarco, P., Chin, M., Randles, C., Diehl, T., and Nielsen, E.: Influence of the 2006 Indonesian biomass burning aerosols on tropical dynamics studied with the GEOS5 AGCM, J. Geophys. Res., 115, D14121, doi:10.1029/2009JD013181, 2010

Price, C. and Rind, D. H.: A Simple Lightning Parameterization for Calculating Global Lightning Distributions, J. Geophys. Res.Atmos., 97, 9919-9933, 1992.

Randerson, J. T., Liu, H., Flanner, M. G., Chambers, S. D., Jin, Y., Hess, P. G., Pfister, G., Mack, M. C., Treseder, K. K., Welp, L. R., Chapin, F. S., Harden, J. W., Goulden, M. L., Lyons, E., Neff, J. C., Schuur, E. A. G., and Zender, C. S.: The impact of boreal forest fire on climate warming, Science, 314, 1130-1132, 2006.

Rinsland, C. P., Luo, M., Shephard, M. W., Clerbaux, C., Boone, C., Bernath, P. F., Chiou, L., and Coheur, P. F.: Tropospheric emission spectrometer (TES) and Atmospheric Chemistry Experiment (ACE) measurements of tropospheric chemistry in tropical southeast Asia during a moderate El Ninõ in 2006, J. Quant. Spectrosc. Radiat. Transf., 109, 1931-1942, doi:10.1016/j.jqst.2007.12.020, 2008.

Sander S. P., Friedl R. R., DeMore W. B., Golden D. M., Kurylo M. J., Hampson R. F., Huie R. E., Moortgat G. K., Ravishankara A. R., Kolb C. E., and Molina M. J.: Chemical Kinetics and Photochemical Data for Use in Stratospheric Modeling. Technical Report JPL Publication 00-3. Jet Propulsion Laboratory, Pasadena, CA, USA, 2000.

Sauvage, B., Martin, R. V., van Donkelaar, A., Liu, X., Chance, K., Jaegle', L., Palmer, P. I., Wu, S., and Fu, T.-M.: Remote sensed and in situ constraints on processes affecting trop- ical tropospheric ozone, Atmos. Chem. Phys., 7, 815-838, doi:10.5194/acp-8-6365-2007, 2007.

Schoeberl, M. R. and Talabac, S.: The SensorWeb: Afuture technique for science return, in Observing Systems for Atmospheric Composition, edited by: Visconti, G., Carlo, P. D., Brune, W. H., Wahner, A., and Schoeberl, M. R., Springer, New York, USA, 203-206, 2006.

Sudo, K. and Takahashi, M.: Simulation of tropospheric ozone changes during 1997-1998 El Ninõ: Meteorological impact on tropospheric photochemistry, Geophys. Res. Lett., 28, 40914094, 2001.

Thompson, A. M., Witte, J. C., Hudson, R. D., Guo, H., Herman, J. R., and Fujiwara, M.: Tropical tropospheric ozone and biomass burning, Science, 291, 2128-2132, 2001.

Tosca, M. G., Randerson, J. T., Zender, C. S., Flanner, M. G., and Rasch, P. J.: Do biomass burning aerosols intensify drought in equatorial Asia during El Niño, Atmos. Chem. Phys., 10, 35153528, doi:10.5194/acp-10-3515-2010, 2010.

Turquety, S., Logan, J. A., Jacob, D. J., Hudman, R. C., Leung, F. Y., Heald, C. L., Yantosca, R. M., Wu, S. L., Emmons, L. K., Edwards, D. P., Sachse, G. W.: Inventory of boreal fire emissions for North America in 2004: Importance of peat burning and pyroconvective injection, J. Geophys. Res., 112, D12S03, doi:10.1029/2006JD007281, 2007.

van der Werf, G. R., Randerson, J. T., Giglio, L., Collatz, G. J., Kasibhatla, P. S., and Arellano Jr., A. F.: Interannual variability in global biomass burning emissions from 1997 to 2004, Atmos. Chem. Phys., 6, 3423-3441, doi:10.5194/acp-6-3423-2006, 2006.

van der Werf, G. R., Dempewolf, J., Trigg, S. N., Randerson, J. T., Kasibhatla, P. S., Giglio, L., Murdiyarso, D., Peters, W., Morton, D. C., Collatz, G. J., Dolman, A. J., and DeFries, R. S.: Climate regulation of fire emissions and deforestation in equatorial Asia, Proceedings of the National Academy of Science, 105, 2035020355, doi:10.1073/pnas.0803375105, 2008a.

van der Werf, G. R., Randerson, J. T., Giglio, L., Gobron, N., and Dolman, A. J.: Climate controls on the variability of fires in the tropics and subtropics, Global Biogeochem. Cycles, 22, GB3028, doi:10.1029/2007GB003122, 2008b.

van der Werf, G. R., Randerson, J. T., Giglio, L., Collatz, G. J., Mu, M., Kasibhatla, P. S., Morton, D. C., DeFries, R. S., Jin, Y., and van Leeuwen, T. T.: Global fire emissions and the contribution of deforestation, savanna, forest, agricultural, and peat fires (1997-2009), Atmos. Chem. Phys., 10, 11707-11735, doi:10.5194/acp-10-11707-2010, 2010.

Wang, Y., D. Jacob, J., and Logan, J. A.: Global simulation of tropospheric $\mathrm{O}_{3}-\mathrm{NO}_{\mathrm{x}}$-hydrocarbon chemistry: 1. Model formulation, J. Geophys. Res., 103, 10713-10726, 1998.

Waters, J. W., Froidevaux, L., Harwood, R. S., Jarnot, R. F., Pickett, H. M., Read, W. G., Siegel, P. H., Cofield, R. E., Filipiak, M. J., Flower, D. A., Holden, J. R., Lau, G. K., Livesey, N. J., Manney, G. L., Pumphrey, H. C., Santee, M. L., Wu, D. L., Cuddy, D. T., Lay, R. R., Loo, M. S., Perun, V. S., Schwartz, M. J., Stek, P. C., Thurstans, R. P., Boyles, M. A., Chandra, K. M., Chavez, M. C., Chen, G. S., Chudasama, B. V., Dodge, R., Fuller, R. A., Girard, M. A., Jiang, J. H., Jiang Y. Knosp, B. W., LaBelle, R. C., Lam, J. C., Lee, K. A., Miller, D., Oswald, J. E., Patel, N. C., Pukala, D. M., Quintero, O., Scaff, D. M., Van Snyder, W., Tope, M. C., Wagner, P. A., and Walch, M. J.: The Earth 
Observing System Microwave Limb Sounder (EOS MLS) on the Aura satellite, IEEE T. Geosci. Remote, 44, 1075-1092, 2006.

Wild, O., Zhu, X., and Prather, M. J.: FAST-J: accurate simulation of in- and below-cloud photolysis in tropospheric chemical models, J. Atmos. Chem., 37, 245-282, 2000.

Yevich, R. and Logan J. A.: An assessment of biofuel use and burning of agricultural waste in the developing world, Global Biogeochem. Cy., 17, 1095, doi:10.1029/2002GB001952, 2003.

Yurganov, L. N., McMillan, W. W., Dzhola, A. V., Grechko, E. I., Jones, N. B., and van der Werf, G. R.: Global AIRS and MOPITT CO measurements: Validation, comparison, and links to biomass burning variations and carbon cycle, J. Geophys. Res., 113, D09301, doi:10.1029/2007JD009229, 2008.

Zhang, G. J. and McFarlane, N. A.: Sensitivity of climate simulations to the parameterization of cumulus convection in the Canadian climate centre general circulation model, Atmos. Ocean, 33, 407-446, doi:10.1029/2005GL022762, 1995.

Zhang, L., Li, Q. B., Murray, L. T., Luo, M., Jiang, J. H., Mao, Y., Chen, D., Gao, M., and Livesey, N.: Effects of lightning and dynamics on tropospheric ozone over the equatorial southern Indian Ocean, in preparation, 2011.
Zhang, Q., Streets, D. G., Carmichael, G. R., He, K., Huo, H., Kannari, A., Klimont, Z., Park, I., Reddy, S., Fu, J. S., Chen, D., Duan, L., Lei, Y., Wang, L., and Yao, Z.: Asian emissions in 2006 for the NASA INTEX-B mission, Atmos. Chem. Phys., 9, 5131-5153, doi:10.5194/acp-9-5131-2009, 2009.

Ziemke, J. R. and Chandra, S.: Seasonal and interannual variabilities in tropical tropospheric ozone, J. Geophys. Res., 104, 21425-21442, 1999.

Ziemke, J. R. and Chandra, S.: La Niña and El Niñoinduced variabilities of ozone in the tropical lower atmosphere during 1970-2001, Geophys. Res. Lett., 30, 1142, doi:10.1029/2002GL016387, 2003.

Ziemke, J. R., Chandra, S., Duncan, B. N., Schoeberl, M. R., Torres, O., Damon, M. R., and Bhartia, P. K.: Recent biomass burning in the tropics and related changes in tropospheric ozone, Geophys. Res. Lett., 36, L15819, doi:10.1029/2009GL039303, 2009. 